\title{
The Usumacinta-Grijalva beach-ridge plain in southern Mexico: a high-resolution archive of river discharge and precipitation
}

\author{
Kees Nooren ${ }^{1}$, Wim Z. Hoek ${ }^{1}$, Tim Winkels ${ }^{1}$, Annika Huizinga ${ }^{1}$, Hans Van der Plicht ${ }^{2,3}$, \\ Remke L. Van Dam ${ }^{4,5,6}$, Sytze Van Heteren ${ }^{7}$, Manfred J. Van Bergen ${ }^{1}$, Maarten A. Prins ${ }^{8}$, \\ Tony Reimann ${ }^{9}$, Jakob Wallinga ${ }^{9}$, Kim M. Cohen ${ }^{1,7,10}$, Philip Minderhoud ${ }^{1}$, and Hans Middelkoop ${ }^{1}$ \\ ${ }^{1}$ Utrecht University, Faculty of Geosciences, 3584 CS Utrecht, the Netherlands \\ ${ }^{2}$ Groningen University, Centre for Isotope Research, 9747 AG Groningen, the Netherlands \\ ${ }^{3}$ Leiden University, Faculty of Archaeology, 2333 CC Leiden, the Netherlands \\ ${ }^{4}$ Centro Federal de Educação Tecnológica de Minas Gerais (CEFET-MG), Department of Civil Engineering, \\ CEP 30510-000, Belo Horizonte, Brazil \\ ${ }^{5}$ Michigan State University, Department of Earth and Environmental Sciences, East Lansing, MI 48824, USA \\ ${ }^{6}$ Queensland University of Technology, Science and Engineering Faculty, Institute for Future Environments, \\ Brisbane, QLD 4001, Australia \\ ${ }^{7}$ TNO - Geological Survey of the Netherlands, Geomodelling Department, 3584 CB Utrecht, the Netherlands \\ ${ }^{8}$ Vrije Universiteit, Faculty of Earth and Life Sciences, 1081 HV Amsterdam, the Netherlands \\ ${ }^{9}$ Wageningen University, Soil Geography and Landscape Group \& Netherlands Centre for Luminescence \\ Dating, 6708 PB Wageningen, the Netherlands \\ ${ }^{10}$ Deltares, Department of Applied Geology and Geophysics, 3584 BK Utrecht, the Netherlands
}

Correspondence to: Kees Nooren (c.a.m.nooren@uu.nl)

Received: 15 April 2017 - Discussion started: 24 May 2017

Revised: 17 July 2017 - Accepted: 2 August 2017 - Published: 8 September 2017

\begin{abstract}
The beach-ridge sequence of the Usumacinta-Grijalva delta borders a $300 \mathrm{~km}$ long section of the southern Gulf of Mexico coast. With around 500 beach ridges formed in the last 6500 years, the sequence is unsurpassed in the world in terms of numbers of individual ridges preserved, continuity of the record, and temporal resolution. We mapped and dated the most extensively accreted part of the sequence, linking six phases of accretion to river mouth reconfigurations and constraining their ages with ${ }^{14} \mathrm{C}$ and OSL dating. The geomorphological and sedimentological reconstruction relied on lidar data, coring transects, GPR measurements, grain-size analyses, and chemical fingerprinting of volcanic glass and pumice encountered within the beach and dune deposits.

We demonstrate that the beach-ridge complex was formed under ample long-term fluvial sediment supply and shorter-term wave- and aeolian-modulated sediment reworking. The abundance of fluvially supplied sand is explained by the presence of easily weatherable Los Chocoyos ignimbrites from the ca. 84 ka eruption of the Atitlán volcano (Guatemala) in the catchment of the Usumacinta River. Autocyclic processes seem responsible for the formation of ridge-swale couplets. Fluctuations in their periodicity (ranging from 6-19 years) are governed by progradation rate, and are therefore not indicative of sea level fluctuations or variability in storm activity. The fine sandy beach ridges are mainly swash built. Ridge elevation, however, is strongly influenced by aeolian accretion during the time the ridge is located next to the beach. Beach-ridge elevation is negatively correlated with progradation rate, which we relate to the variability in sediment supply to the coastal zone, reflecting decadal-scale precipitation changes within the river catchment. In the southern Mexican delta plain, the coastal beach ridges therefore appear to be excellent recorders of hinterland precipitation.
\end{abstract}




\section{Introduction}

Beach-ridge plains with long sequences holding many individual ridges consisting of coral rubble, shell hash, cobbles, gravel, and/or sand are widely distributed across the globe. They have developed along marine shores and lakeshores under favourable wind and wave conditions and sufficient longterm sediment supply.

During the past few decades, research on beach-ridge sequences has progressed from describing their morphology and possible origins (Taylor and Stone, 1996; Otvos, 2000) to enabling their usage for palaeoenvironmental reconstructions. They can be used to assess external controls of (relative) sea level rise, land subsidence, variations in storm impact, and changes in climate and upstream land use (Scheffers et al., 2012; Tamura, 2012 and references therein). They may also include markers left by catastrophic events like volcanic eruptions (Nieuwenhuyse and Kroonenberg, 1994; Nooren et al., 2017) and host soils that are suitable for chronosequence studies (Nielsen et al., 2010; May et al., 2015; Hinojosa et al., 2016).

The number of preserved ridges determines the extent of the palaeoenvironmental record stored in the associated sediments, with resolutions up to the decadal scale (Curray et al., 1969; Nielsen et al., 2006; Milana et al., 2017). The largest beach-ridge plains with multiple parallel beach ridges are formed along the medium- to low-energy shorelines of lakes and seas. The beach-ridge plain on the seaward margin of the terrestrial Usumacinta-Grijalva delta in southern Mexico (Fig. 1a) is probably the world's largest. Since the significant reduction in the rate of postglacial sea level rise in the mid-Holocene, hundreds of semi-parallel sandy beach ridges formed across a shore-perpendicular distance of more than $20 \mathrm{~km}$. In our study area near Frontera (Fig. 1b), beach ridges include aeolian topsets composed of backshorefringing foredunes. In this paper, we use Otvos's (2000) broad definition of beach ridges, including all "relict, semiparallel, multiple ridges" formed by waves (berm ridges), wind (multiple ridges originating as foredunes), or a combination of both.

Earlier morphological studies (Psuty, 1965, 1967; West et al., 1969) identified three main phases in the development of the Usumacinta-Grijalva beach-ridge plain, each linked to a specific position of the rivers' main channels (Fig. 1b). The north-easterly branches of the Grijalva river system created favourable conditions for local beach-ridge complex initiation and development during Phase 1, the Usumacinta (with the San Pedro y San Pablo River; SP y SP in Fig. 1b) as the main outlet during Phase 2, and both rivers (though a combined outlet near Frontera) during Phase 3 . Psuty $(1965,1967)$ proposed an important role in storm surges and overwash in the formation of the beach ridges. Aguayo et al. (1999) established a preliminary chronology

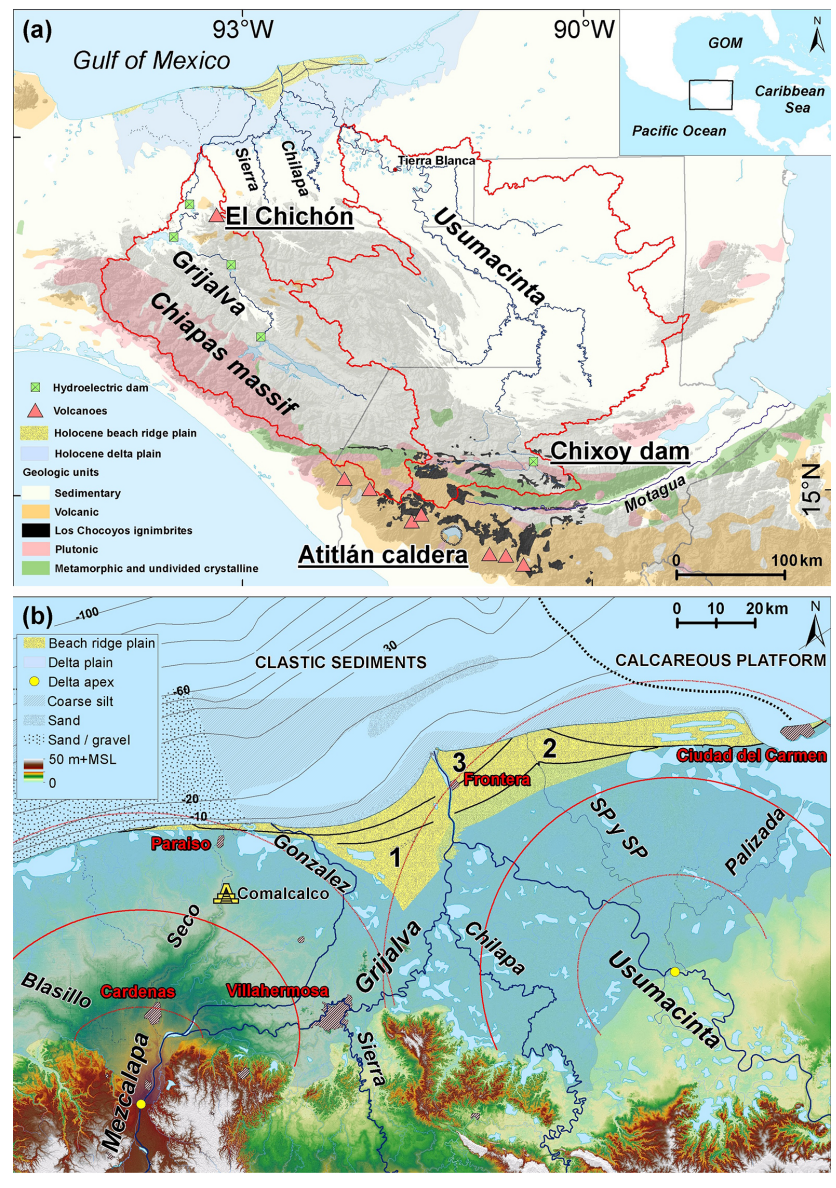

Figure 1. (a) Location of the Usumacinta-Grijalva beach-ridge sequence (yellow) along the edge of the Holocene delta plain (blue) and the drainage basins of the two main rivers traversing the headlands of this delta (red outlines). Simplified geological map modified from Garrity and Soller (2009) and extent of Los Chocoyos pyroclastic flow deposits adopted from the geological map of Guatemala at scale 1:500000 (Instituto Geográfico Nacional, 1970; Koch and McLean, 1975; Rose et al.,1987; and Sánchez-Núñez et al., 2015). Elevated uplands above 500 ma.m.s.l. outlined using the SRTM 1 arcsec dataset (USGS, 2009) are depicted in grey. (b) Overview of the Usumacinta-Grijalva delta and the three main phases of Holocene beach-ridge formation defined by Psuty $(1965,1967)$. The apexes of the two main rivers (yellow dots) are indicated with 25,50 , and $75 \mathrm{~km}$ equidistant lines (red lines). Nearshore distribution of coarse silty to gravelly surficial sediments after Ayala-Castañares and Guttiérrez-Estrada (1990). Surficial sediments from the remaining part of the continental shelf are composed of clay and fine silt.

of beach-ridge formation on the basis of radiocarbon-dated bivalves and gastropods. Our study elaborates on these pioneering works aims to establish a robust chronology for the beach-ridge sequence and to understand the apparent periodical variations in beach-ridge height that are seen in lidar imagery of the study area (Fig. 2a). 


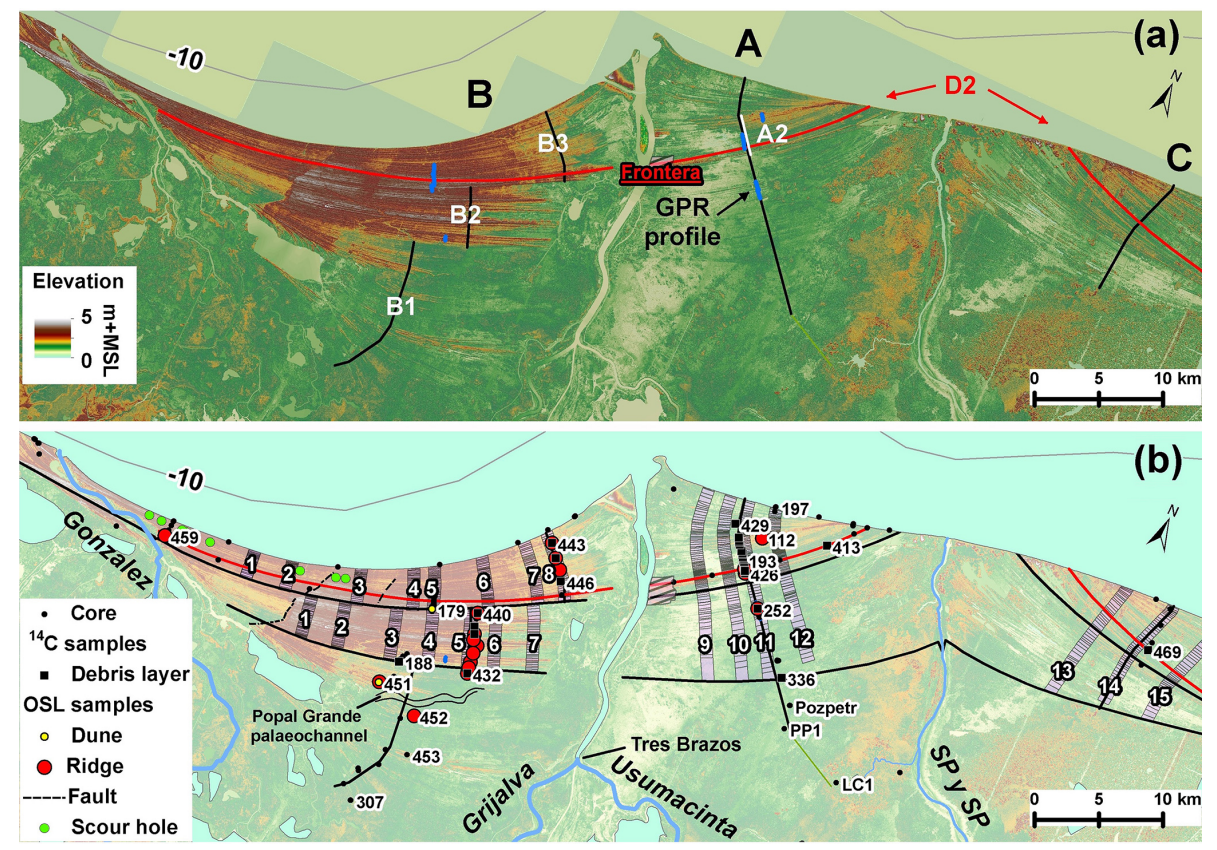

Figure 2. (a) Lidar-based DEM and location of studied transects with the GPR transects in blue. (b) Main beach-ridge formation phases and the locations of sediment cores (black) and samples collected for OSL and AMS ${ }^{14} \mathrm{C}$ dating. Numbers $1-15$ denote the 15 cross-normal ribbon-shaped elevation transects, in the text referred to as B2-1, B2-2, etc.

In the long term $\left(10^{3} \mathrm{yr}\right)$, the considerable accretion of the beach-ridge complex has been driven by steady sediment supply by the Usumacinta and Grijalva rivers (West et al., 1969). Much of this sediment has been generated in their upper catchments and routed through the delta plain to the coastal zone. Morphometric variations between the main phases of beach-ridge formation (Fig. 1b) are mainly influenced by spatiotemporal variability in the positions of the river mouths, the size of the feeding river, and the magnitude of sediment fluxes carried by the water. Studies on other beach-ridge systems suggest that shorter-term $\left(10^{1}-\right.$ $10^{2} \mathrm{yr}$ ) variability can reflect oscillations in river mouth sediment supply (Brooke et al., 2008a; Tamura, 2012), potentially making the Usumacinta-Grijalva beach-ridge sequence a proxy record for variability in precipitation in the hinterland.

To test this hypothesis, we conducted a detailed geomorphological and sedimentological field study linking lidar data to cored and geophysically surveyed transects and extensive sediment analyses and dating. Our study covers $150 \mathrm{~km}$ of the beach-ridge complex in a shore-parallel direction and $20 \mathrm{~km}$ in a shore-normal direction. Grain-size and mineralogical analyses are potentially powerful tools to understand transport and deposition mechanisms of beach-ridge sands (Visher, 1969), but they have scarcely been applied in recent beach-ridge studies (exceptions are Guedes et al., 2011; Garrison et al., 2012). Volcanic glass and pumice fragments are highly informative components of the beach-ridge sands (Nooren et al., 2017) and have been chemically fingerprinted to determine their provenance. The internal architecture of the beach ridges was imaged with ground-penetrating radar (GPR), as in other beach-ridge and coastal barrier studies (e.g. Jol et al., 1996; Van Heteren, 1998; Bristow and Pucillo, 2006; Forrest, 2007; Oliver, 2016).

A detailed chronology of the sequence was established from the combined deployment of optically stimulated luminescence (OSL) on quartz grains (quartz content of the sand is 50 to $65 \%$; Aguayo et al., 1999) and AMS ${ }^{14} \mathrm{C}$ dating of thin layers of terrestrial organic debris (leaf fragments) in the beach-ridge sand. Here we expand on the chronology of a $3 \mathrm{~km}$ long beach-ridge subsection documented in Nooren et al. (2017). Quartz-grain OSL dating has been widely used for establishing the age of coastal deposits in general (e.g. Ballarini et al., 2003; Nielsen et al., 2006; Reimann et al., 2011) and beach-ridge sequences in particular (Tamura, 2012 and references therein; Oliver et al., 2015; Rémillard et al., 2015; Vespremeanu-Stroe et al., 2016; Milana et al., 2017), but its combination with the AMS ${ }^{14} \mathrm{C}$ dating of thin organic debris layers is presented here for the first time. It provides a unique opportunity for cross-validating the methods.

\section{Geographical setting}

The study area is part of the beach-ridge system along the edge of the Holocene Usumacinta-Grijalva delta plain and stretches from Paraiso in the west to Ciudad del Carmen in the east (Fig. 1b). The delta plain and its hinterland have a humid tropical climate with mean annual precipitation ranging 
Table 1. General characteristics for the watersheds of the main rivers draining towards the Usumacinta-Grijalva delta.

\begin{tabular}{lcccrc}
\hline Catchment & Areal extent & $\begin{array}{r}\text { Average annual } \\
\text { precipitation } \\
\left(\mathrm{mm} \mathrm{yr}^{-1}\right)^{1}\end{array}$ & $\begin{array}{r}\text { Average annual } \\
\text { discharge } \\
\left(\mathrm{m}^{3} \mathrm{~s}^{-1}\right)^{2}\end{array}$ & $\begin{array}{r}\text { Excess } \\
\text { rainfall } \\
(\%)\end{array}$ \\
\hline Usumacinta & 70714 & 58 & 2150 & 2000 & 41 \\
Grijalva & 37471 & 31 & 1500 & 750 & 42 \\
Sierra-Chilapa system & 12840 & 11 & 2550 & 600 & 58 \\
\hline
\end{tabular}

\footnotetext{
${ }^{1}$ Mean value for the watershed calculated over the period 1950-2000 (WorldClim version 1.4, release 3; Hijmans et al., 2005).

${ }^{2}$ Estimated valued based on measured discharges at the different hydrological stations (Banco Nacional de Datos de Aguas

Superficiales; consulted in Jun 2016).
}

from 1000 to $1500 \mathrm{~mm}$ in the highlands of the Chiapas massif and along the Tabasco coast to locally more than $5000 \mathrm{~mm}$ in the mountain foothills in between (West et al., 1969; Hijmans et al., 2005). Approximately $80 \%$ of the annual precipitation falls in a rainy season that lasts from June until November. The excess or effective precipitation contributing to river discharge is around 40-60\% (Table 1). Peak discharges are related to the passage of large tropical depressions most frequently occurring in September and October.

The drainage basin of the Usumacinta River is dominated by a Cretaceous limestone plateau, which was folded during the Palaeogene (Padilla and Sanchez, 2007), with elevations rarely exceeding $700 \mathrm{~m}$ above mean sea level (ma.m.s.l.). The headwater catchments of this river, however, are composed of pre-Mesozoic plutonic, metamorphic, and volcanic rocks (Fig. 1a). These uplands are dotted with large remnants of Los Chocoyos ignimbrites left by a Pleistocene calderaforming eruption at the Atitlán volcanic centre in southern Guatemala. The Los Chocoyos ignimbrites are also found in the upper drainage basin of the Grijalva River up to $130 \mathrm{~km}$ from the Atitlán caldera (Sánchez-Núñez et al., 2015), but to a smaller extent than the deposits within the Usumacinta drainage basin.

Presently, the routing of sediment from the upstream to downstream reaches of the Usumacinta River is blocked by the Chixoy hydroelectric dam at Pueblo Viejo (Fig. 1a). This man-made obstacle has reduced sediment transport to the coast since its completion in 1983. High erosion rates have caused rapid infill of the reservoir behind the dam. Between 1983 and 2009, approximately $158 \times 10^{6} \mathrm{~m}^{3}$ of sediment accumulated at an average rate of $6.1 \times 10^{6} \mathrm{~m}^{3} \mathrm{yr}^{-1}$ (Jom Morán, 2010). The total volume of upland source material and the rate at which it is transported downriver show that the Usumacinta could have contributed a sufficient amount of sediment for the rapid progradation of the beach-ridge plain. Nieuwenhuyse and Kroonenberg (1994) demonstrated a similar important role of volcaniclastic sediments in the formation of Holocene beach ridges in Costa Rica.

The coastal zone experiences a diurnal tide with a microtidal range between 0.25 and $0.75 \mathrm{~m}$. During most of the year, low-energy waves coming from the north-east with swells of 0.3 to $0.7 \mathrm{~m}$ produce a wave-generated longshore current carrying river sediments westwards (West et al., 1969). Under these fair weather conditions, beach accretion is common (Psuty, 1965, 1967), building out the promontories of active river mouths. Usually some 20 to 25 "Nortes" or frontal storms hit the area between October and March. These produce strong north-westerly winds generating swells of 1.2 to $1.7 \mathrm{~m}$ and local longshore current reversals and commensurate beach erosion (West et al., 1969). Wave climate increases westward in the dominant longshore current direction, reflected by relatively steeper shoreface slopes in the western part of the study area (notice the $10 \mathrm{~m}$ depth contour in Fig. 1b). Newly formed beach ridges are rapidly colonised and stabilised by vegetation, most noticeably and dominantly by Ipomoea pes-caprae, a salt-tolerant coastal pioneer species (Castillo et al., 1991; Gallego-Fernández and Martínez, 2011). Hurricanes are a frequent phenomenon in the Gulf of Mexico (e.g. Kossin et al., 2010), but they generally pass over the middle and northern part, whereas landfall at or near the study site is rare (www.nhc.noaa.gov/data/ \#tracks_all).

\section{Materials and methods}

\subsection{Geomorphological and sedimentological survey}

The lidar data (Fig. 2a) were originally acquired in AprilMay 2008 and processed by Mexico's National Institute of Statistics and Geography (INEGI). The derived DEM product has a cell size of $5 \times 5 \mathrm{~m}$, centimetre-scale vertical resolution, and accuracy to $0.15-0.30 \mathrm{~m}$ (Ramos et al., 2009). The lidar imagery is used to morphometrically distinguish main phases and sub-phases of progradational beach-ridge formation, focusing on internal similarity in ridge dimensions, orientation, and lateral and cross-cutting relationships with river channel morphology. We identified and defined sub-phases that correspond to periods of relatively stable river mouth configurations, with smaller and larger river network reconfigurations as the breaks between.

Lidar-inferred morphometric phases were ground-truthed using sediment composition and chronometric results from four field campaigns in the period 2011-2015. To describe and sample the sandy, waterlogged lithology, sediment cores 
(a) Elevation (m a.m.s.I.)

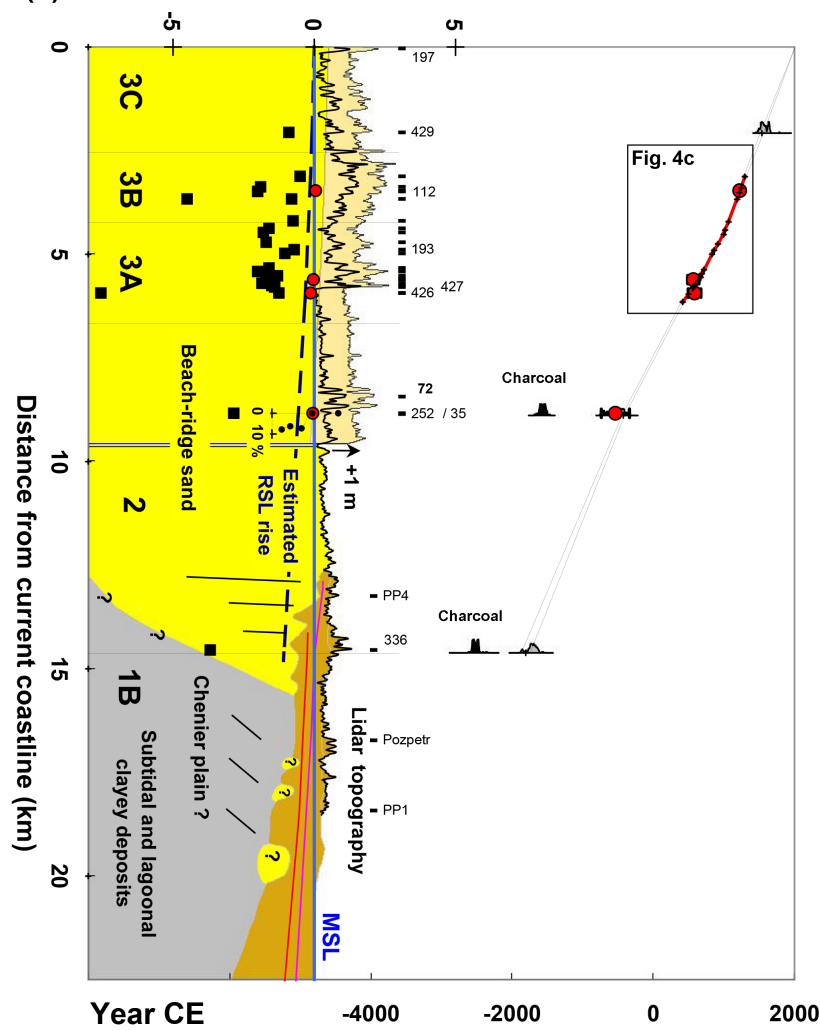

Figure 3.

reaching 4 to $11 \mathrm{~m}$ of depth were taken with a soil auger and a Van der Staay suction corer (Van de Meene et al., 1979). Boreholes were placed along three shore-normal (A, B, and C) and two shore-parallel (D1, the youngest beach ridge, and D2) transects (Fig. 2a). To support the interpretation of the grain-size data, surficial nearshore sediments were sampled off Playa Estrella in April 2013 for modern analogue study of the shore-normal sorting processes.

The shore-parallel transects aimed at characterising the aeolian facies encountered on the most recent beach ridge and the swash facies encountered at $\sim 1 \mathrm{mb}$. m.s.l. in a relatively elevated fossil beach ridge. The shore-normal transects aimed at establishing the progradational chronology and its relation with river shifts, with densest sampling along Transects A and B (Fig. 2b). A $3 \mathrm{~km}$ long subsection of Transect A, containing evidence for a volcanic eruption of El Chichón in $540 \mathrm{CE}$, was studied in substantial detail (Nooren et al., 2017). For consistency, each coring location was chosen at the seaward foot of an individual ridge, except when the aeolian cap on top of the ridges was sampled. Bagged samples of sand were collected at $0.2-0.5 \mathrm{~m}$ core intervals. Encountered organic debris-rich layers were sampled and stored in a cold room $\left(4^{\circ} \mathrm{C}\right)$ pending further processing for AMS ${ }^{14} \mathrm{C}$ dating. For OSL dating, 19 samples were collected in $30 \mathrm{~cm}$ long opaque tubes from the bottom of shallow hand-augered bore-

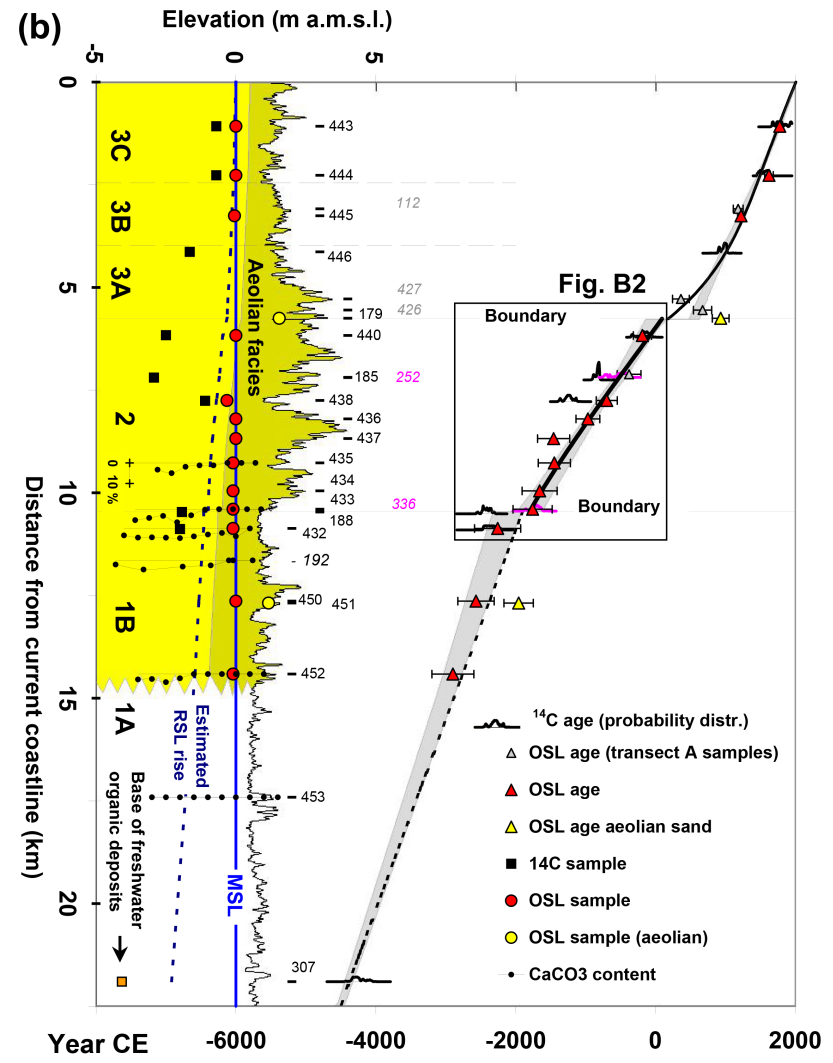

Figure 3. Age-distance models for Transects A (a) and B (b). Indicated are the $1 \sigma$ distributions for the model results using the P_sequence module in Oxcal 4.2 (Bronk Ramsey, 2009). Sample locations of AMS ${ }^{14} \mathrm{C}$ (black squares) and OSL (red dots) samples are indicated, and projected samples are presented in italics. The calibrated ${ }^{14} \mathrm{C}$ ages are indicated with the full probability distribution and the OSL ages (red and yellow triangles) with their $1 \sigma$ range. $\mathrm{CaCO}_{3}$ content for selected core samples indicates pedogenic decalcification depth used to estimate the position of m.s.l. during beach-ridge formation. The dashed trendline is based on Gischler and Hudson's (2004) reconstruction of late Holocene RSL.

holes during the dry seasons of 2012 and 2013. OSL sample 450 was collected from a soil pit dug in a beach ridge for use in a chronosequence study (Hinojosa et al., 2016).

More than 1000 sand samples were collected in the field, transported to the Netherlands, dried at $105^{\circ} \mathrm{C}$, and stored at room temperature. Magnetic susceptibility was measured on all dried sand samples with a handheld $\mathrm{ZH}$ Instruments SM30. Calcium carbonate was measured on sand samples from the two shore-parallel transects and on sand samples from cores 192, 252, 432, 433, 435, 452, and 453 (Fig. 3) to estimate the maximum depths of pedogenic decalcification, which indicates the position of the phreatic surface (groundwater level and, by proxy, m.s.l.). Calcium carbonate was measured with a Scheibler calcimeter by adding a $10 \% \mathrm{HCl}$ solution to $1 \mathrm{~g}$ of sediment and measuring the produced $\mathrm{CO}_{2}$ volumetrically. Carbonate content is expressed as 
weight percentage $\mathrm{CaCO}_{3}$. Grain-size analyses (range 0.15$2000 \mu \mathrm{m}$ ) were conducted with a Sympatec HELOS/KR laser diffraction particle sizer, equipped with an advanced wet disperser (QUIXEL). Before measurements, organic matter and carbonates were removed with $20 \% \mathrm{H}_{2} \mathrm{O}_{2}$ and $10 \% \mathrm{HCl}$. Grain-size parameters (median, sorting, skewness, and kurtosis) were calculated with the logarithmic method of moments (Folk and Ward,1957; Blott and Pye, 2001).

Grain-size and magnetic susceptibility investigations were supported by a limited number of heavy mineral analyses to characterise the source material. Heavy minerals were separated with a heavy liquid solution (sodium polytungstate, $\left.\mathrm{Na}_{6}\left[\mathrm{H}_{2} \mathrm{~W}_{12} \mathrm{O}_{40}\right]\right)$ with a density of $2.85 \mathrm{~g} \mathrm{~cm}^{-3}$ and identified under a polarised light microscope. Volcanic glass shards and a pumice clast retrieved from four beach-ridge cores along Transect A, covering a large temporal range in beach-ridge formation (Figs. 2b and 3a; samples 336, 252, 193, and 197), were chemically fingerprinted to identify the eruption source(s). Major-element compositions of the glass shards were determined on 5-12 particles per sample with a Jeol JXA-8600 microprobe equipped with five wavelengthdispersive spectrometers. Measurements were performed by wavelength-dispersive spectroscopy (WDS) using $15 \mathrm{kV}$ of acceleration voltage, a $10 \mathrm{nA}$ beam current, and a defocused beam ( $5 \mu \mathrm{m}$ spot size) to minimise the mobilisation of sodium. Instrumental performance and calibration were monitored by repeated analyses of natural glass standards (rhyolitic USNM 72854 VG-568 and basaltic USNM 111240 VG-2) and in-house mineral standards.

\subsection{AMS radiocarbon and OSL dating}

Within the beach ridges, 1 to $5 \mathrm{~cm}$ thick layers of organic debris were commonly found, especially at locations relatively close to a (former) river mouth (Transects A and B3). The layers contained charcoal, wood, and leaf fragments often mixed with shell fragments. This organic material is transported to the coast by the rivers and then further distributed by longshore currents to eventually be incorporated into the beach-ridge facies. The debris is a mixture of apparently younger (hardly physically weathered) and older (rounded edges) reworked material. Reworking was especially evident from the commonly rounded edges of wood and charcoal fragments in the detritus cocktail. Reworked organic material was purposely avoided in our sampling (apart from test samples to demonstrate the associated danger of age overestimation) and age-distance modelling.

Thirty-five terrestrial macro-remains (mainly leaf fragments), isolated from organic debris layers, were standard AAA pretreated and ${ }^{14} \mathrm{C}$ dated using an AMS facility (Van der Plicht et al., 2000). Ages were reported in yr BP using the Libby half-life and corrected for isotopic fractionation via $\delta^{13} \mathrm{C}$ (Mook and Van der Plicht, 1999). They were calibrated with the software package Oxcal 4.2 (Bronk Ramsey, 2009) using the IntCal13 calibration curve (Reimer et al., 2013).
Twenty OSL samples were dated using Ris $\emptyset$ TL/OSL DA15/20 readers (Bøtter-Jensen et al., 2003) equipped with ${ }^{90} \mathrm{Sr} /{ }^{90} \mathrm{Y}$ beta source. About $130 \mathrm{~g}$ of material from the (light-exposed) outer parts of the sample tubes was used for dose rate determination. High-resolution gamma spectrometry was used to determine radionuclide activity concentrations $\left({ }^{40} \mathrm{~K}\right.$ and several nuclides from the $\mathrm{U}$ and $\mathrm{Th}$ decay chains). Measured values were converted to environmental dose rates using the conversion factors of Guerin et al. (2011), assuming immediate burial of the samples to present depth and accounting for attenuation due to water, organic material (Aitken, 1998), and cosmic ray contributions (Prescott and Hutton, 1994). For OSL samples obtained from below the groundwater table, a water content of $25 \pm 5 \%$ by weight was used (pore space fully water saturated), assuming permanent saturation over the entire burial period. For some of the older samples, it is likely that they were deposited above contemporary groundwater levels (Fig. 3b). However, at this stage it is not possible to make a more realistic estimation of the average water content over the entire burial period. Dependency of dose rates and hence OSL ages on water content implies that OSL age estimates will decrease by approximately $1 \%$ for each weight $\%$ decrease in water content (Aitken, 1998). For two OSL samples taken above the groundwater table, a water content of $5 \pm 3 \%$ was used (moisture contents at field capacity).

OSL samples were prepared following standard procedures including sieving and chemical treatment with $\mathrm{H}_{2} \mathrm{O}_{2}$, $\mathrm{HCl}$, and $\mathrm{HF}$ to yield sand-sized purified quartz of 212 $250 \mu \mathrm{m}$. For aeolian sample 179 , the fraction $180-212 \mu \mathrm{m}$ was used. Quartz OSL signals were detected through a $7.5 \mathrm{~mm}$ Hoya U340 filter, and an early background approach was applied to obtain a net signal that is dominated by the fast OSL component of quartz (Cunningham and Wallinga, 2010). The OSL IR depletion ratio of Duller (2003) was used to check for feldspar contamination. Equivalent doses were determined on small aliquots ( $2 \mathrm{~mm} ; \sim 60$ grains) using the single aliquot regenerative dose procedure (Murray and Wintle, 2003). The central age model (CAM; Galbraith et al., 1999) was used to determine overdispersion in the resulting equivalent dose distributions (i.e. spread in results on individual aliquots that is not explained by the analytical uncertainties) and for burial dose estimation. In the case of high overdispersion $(>30 \%)$ in combination with a skewed dose distribution (sample 444), the burial dose was estimated using a bootstrapped version of the minimum age model (Cunningham and Wallinga, 2012). OSL ages are determined by dividing the sample burial dose by the sample dose rate and reported in $\mathrm{yr} \mathrm{CE}$ with $1 \sigma$ uncertainty ranges. For each sample, the validity of the OSL age was assessed on the basis of the equivalent dose distribution.

The full set of calibrated AMS ${ }^{14} \mathrm{C}$ and OSL ages was used to establish an age-distance model using the $\mathrm{P}_{-}$sequence module of the Oxcal 4.2 programme (Bronk Ramsey, 2009, 2016). We furthermore demonstrate the variability in age- 
distance models for part of Transect B if we assume a constant aeolian accretion rate, following the approach of Minderhoud et al. (2016).

\subsection{Ground-penetrating radar}

The GPR method is based on the transmission and propagation of electromagnetic energy, commonly at frequencies between 25 and $1000 \mathrm{MHz}$. It has become a popular non-invasive tool to characterise the sedimentary structures of coastal landforms (Neal, 2004; Tamura, 2012; Van Dam, 2012). To generate 2-D images of the subsurface, a pair of transmitting and receiving antennas is moved across the surface while collecting measurements at regular, predefined intervals. Signal reflections are caused by contrasts in dielectric properties between layers, which in turn are induced by changes in textural properties and water content, among others (Van Dam and Schlager, 2000).

GPR surveys were conducted at the end of the dry season in June 2012 along parts of the transects (Fig. 2a). Data were collected using a MALA ProEx system with $250 \mathrm{MHz}$ shielded antennas and an odometer wheel for accurate positioning ( $0.1 \mathrm{~m}$ step size). Processing of the data included signal dewow to remove low-frequency content, a custom gain function to amplify deeper reflections, background removal below the direct waves to reduce the effect of antenna ringing, and topographic correction. For the time-todepth conversion, we used signal velocities of 0.125 (based on the move-out of diffraction hyperbolas) and $0.06 \mathrm{~m} \mathrm{~ns}^{-1}$ for deposits above and below the groundwater table, respectively. Interpretation of the internal structures was guided by common criteria for GPR facies analysis, including reflection continuity and amplitude, dip angle, and reflection terminations (van Overmeeren, 1998; Dogan et al., 2011).

\subsection{Beach-ridge elevation and accretion volumes}

Fifteen shore-normal ribbon-shaped elevation transects (Fig. 2b) were sampled from the lidar-based DEM and combined with the dating information to calculate the temporal variability in beach-ridge elevation and accretion volumes. To exclude short-term variability in beach-ridge elevation and to minimise the effect of local erroneous elevation values, we divided the $1 \mathrm{~km}$ wide ribbons into multiple polygons (Fig. 2b). Each polygon included at least one, but on average a few, ridge-swale couplets.

We estimated an average thickness for the Holocene sandy beach-ridge complex of $10 \pm 2 \mathrm{~m}$ based on geophysical tests conducted near the current combined Usumacinta-Grijalva outlet (Administración Portuaria Integral de Dos Bocas S.A. de C.V., 2005). Unfortunately, we have limited information regarding the inland spatial variability in thickness of the beach-ridge complex, and our deepest Van der Staay core of $11 \mathrm{~m}$ (core 426; Figs. 3a and 4) did not penetrate the base of the Holocene beach-ridge deposits at this location. (a)

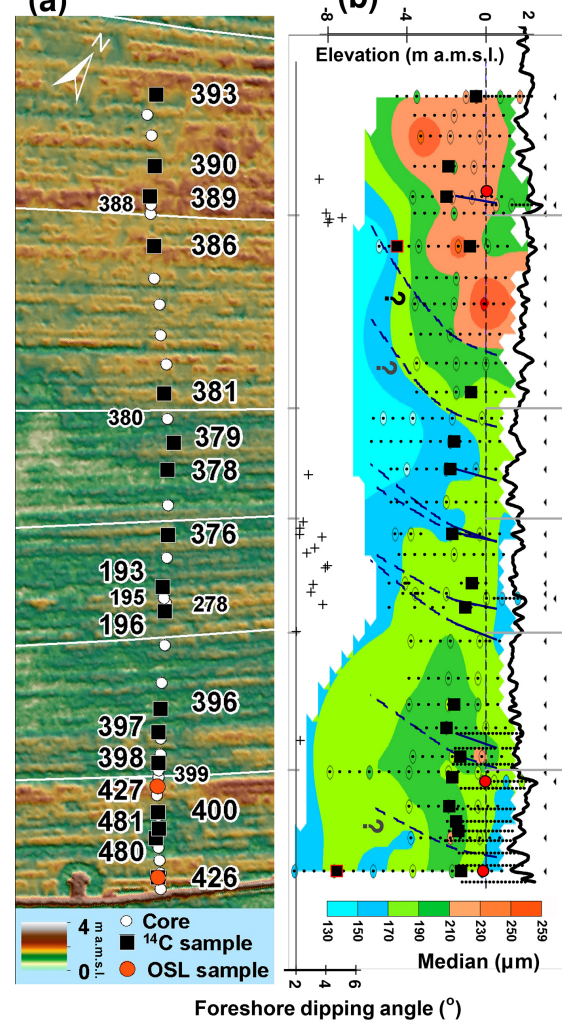

(c)

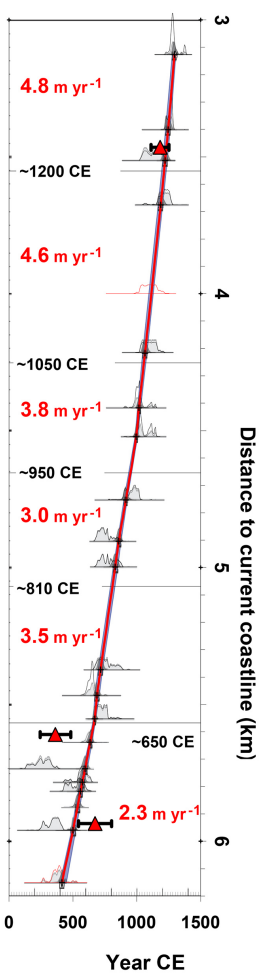

Figure 4. (a) Core locations along Transect A2; (b) median grain size of analysed sand samples with associated shoreface-dipping angle; (c) age-distance model (after Nooren et al., 2017) and OSL ages (red dots; with $1 \sigma$ probability).

Aeolian accretion sub-volumes were calculated from the ribbon-averaged estimated mean beach-ridge elevation. The calculation assumed all sandy deposits above an estimated average swash run-up height of $0.5 \pm 0.5 \mathrm{~m}$ a.m.s.l. at the time of beach-ridge formation to be aeolian in origin. We used our decalcification depth observations (which are decimetres deeper than the current groundwater level at more inland beach ridges) and the resemblance of this signal with Gischler and Hudson's (2004) relative sea level (RSL) curve for Belize to assess the m.s.l. positions at the time of beachridge formation. The calculations were performed for Phase 2 and Phase 3. Along Transect A we added $1 \mathrm{~m}$ to the raw lidar DEM values because the surface elevations as estimated during the fieldwork period were systematically $1 \mathrm{~m}$ higher than the first-generation DEM product for this sub-area. We assume that the groundwater level by the end of the dry season in 2012 and 2013 should at least correspond to or be above present m.s.l., as was the case at core locations along Transects B and C. Given the temporal and spatial variability in run-up height, the uncertainties in the absolute elevation of beach-ridge sand samples, late Holocene estimated RSL rise, and the limited amount of grain-size data, calculated aeolian accretion rates must be regarded indicative only. 


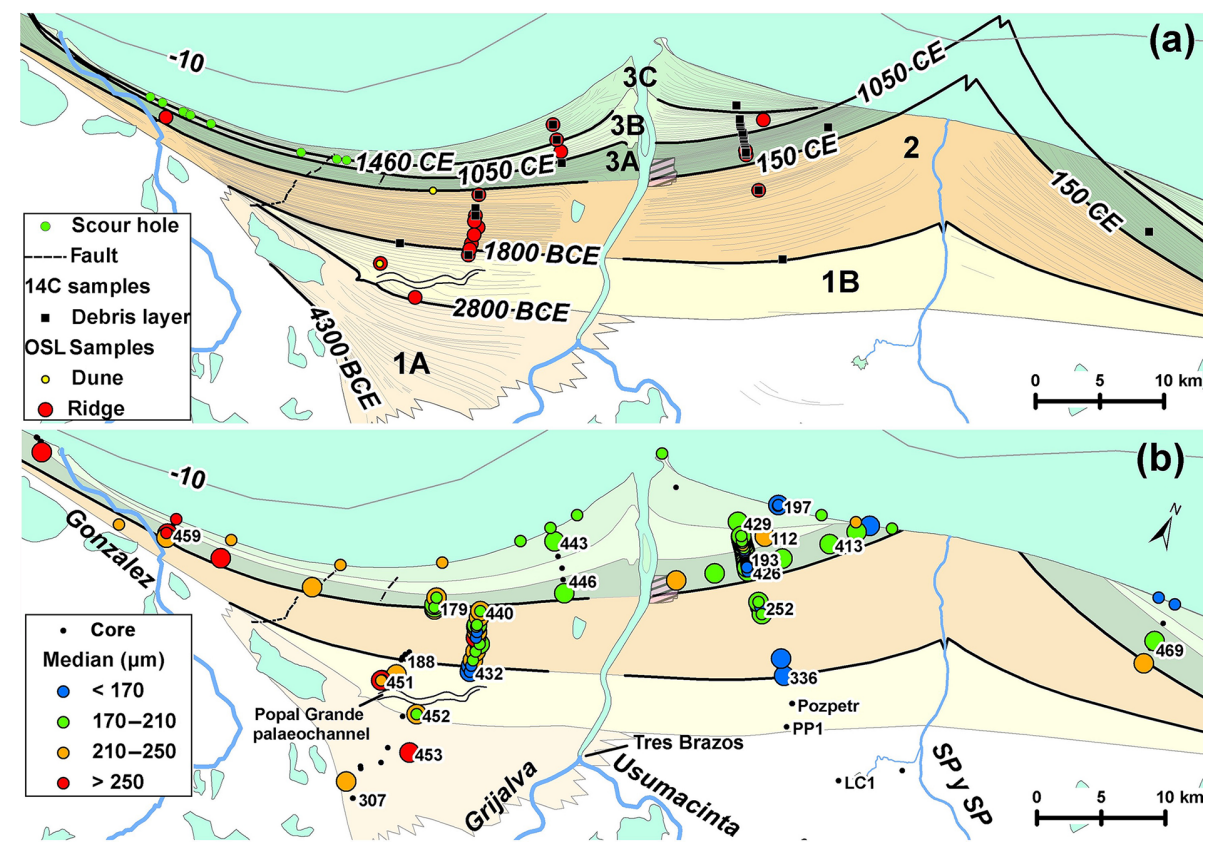

Figure 5. (a) Reconstructed palaeoshorelines (ages in yr CE); (b) median grain size ( $\mu \mathrm{m})$ of wave-formed and aeolian deposits (large and small dots, respectively).

\section{Results}

\subsection{Lidar DEM analyses}

The three main phases in beach-ridge formation (Psuty, 1965, 1967; West et al., 1969) are easily discernible from the lidarbased DEM (Fig. 2a). Approximately 500 beach ridges can be distinguished. Their spacing is typically between 20 and $100 \mathrm{~m}$, and mean surface elevations along the three shorenormal transects vary between 0.5 and 3.5 ma.m.s.l. (Fig. 3). Beach ridges are relative low and widely spaced near (former) river mouths. Away from a river mouth they merge or become more closely spaced. Beach-ridge elevation, however, tends to increase with distance from a river mouth. The most elevated beach ridges (up to $5 \mathrm{ma}$ a.m.s.l.) are found in the western part of the study area (Fig. 2a) on the downdrift side of the system. The influence of drift direction is also apparent in the modest asymmetry of the truncated Phase 2 promontory at the mouth of the SP y SP River and in the strong westward deflection of the mouth of the Gonzalez River (Fig. 2b).

Two faults (Fig. $2 b$ ), $0-45^{\circ}$ perpendicular to the orientation of the beach ridges, may be responsible for the slight eastward-dipping tilt of ridges in this part of the study area. The DEM shows no evidence of the significant horizontal displacement along NW-SE-oriented strike-slip faults described by Aguayo et al. (1999).

Scour holes, possible features produced by large storm surges, are clearly identifiable along only one beach ridge in the western part of the study area (Figs. $2 \mathrm{~b}$ and B1), and washovers are not apparent from the DEM, indicating that few extreme storm events left clear traces in the area.

\subsection{Beach-ridge chronology}

The 35 AMS ${ }^{14} \mathrm{C}$ and 20 OSL sample ages (Figs. 2b, 3, and 4; Tables A1 and A2) offer a significant refinement of the preliminary beach-ridge chronology proposed by Aguayo et al. (1999) on the basis of radiocarbon-dated shell material. The resolution offered by the large number of dated samples facilitated the development of age-distance models for the progradation of the beach-ridge plain (Figs. 3 and 4) used in turn to reconstruct the palaeoshorelines as indicated in Fig. 5a.

The sequence of calibrated ${ }^{14} \mathrm{C}$ ages shows very good internal consistency, with only two statistically significant age reversals (both in Transect A2; Fig. 4c). This more than fair agreement of ${ }^{14} \mathrm{C}$ ages with vertical stratigraphic order, and lateral geographic position gives confidence to their representativeness for deposition age. Nevertheless, dated organic detrital fragments give terminus ante quem ages that may be older than the beach-ridge sand in which they were entrained. Charcoal fragments have been found to be many hundreds of years older than the more fragile leaf fragments from the same debris layer (Fig. 3a and Table A1; sample 252 and 336) and do not provide a reliable age of final deposition. We therefore avoided wood and charcoal in our sample analysis and only used dated leaf fragments for the age-distance models (Fig. 3). Of all the terrestrial macro-remains in the organic debris layers, fragile leaves are assumed to be the least likely 
to have survived repeated reworking. There are some indications, however, that even the leaf fragments have undergone some reworking because samples taken farther from the former river mouth in Transect B2 appear to be 200-500 years older than the lidar-tracing-projected AMS ${ }^{14} \mathrm{C}$ ages of samples taken closer to the river mouth in Transect A (Figs. 3b and B2).

Quartz OSL behaviour of the samples showed suitability for dating. A dose recovery experiment indicated that a given dose could be retrieved accurately (dose recovery ratio $0.997 \pm 0.014 ; n=39$ ). Equivalent dose distributions were normally distributed and showed overdispersion as expected for well-bleached deposits (average $18 \% ; n=17$ ). For three samples $(179,427$, and 444), higher overdispersion $(>30 \%)$ was observed. The reliability of samples 179 and 427 was considered questionable because the equivalent dose distributions lacked the skewness that would characterise overdispersion due to heterogeneous bleaching (e.g. Wallinga, 2002).

Although volcanic quartz from certain types of volcanic deposits has inappropriate OSL properties for dating (e.g. Tsukamoto et al., 2003), Pietsch et al. (2008) demonstrated that OSL sensitivity of quartz increases linearly with fluvial transport distance for the Castlereagh River in Australia. Such a sensitisation effect might explain the decent the OSL sensitivity of our samples, even if they started as ignimbrites with poor OSL sensitivity in the upper catchment $(\sim 1100 \mathrm{~km}$; see Sect. 4.5). Another explanation could be sought in a secondary source of quartz with high luminescence sensitivity. Even if the bulk of the sediment is from ignimbrites, a minor component from another source may be responsible for the observed OSL signal.

Dose rates were found to vary between $1.83 \pm 0.08$ and $2.66 \pm 0.10 \mathrm{~Gy} \mathrm{ka}^{-1}$ (mean $2.18 \mathrm{~Gy} \mathrm{ka}^{-1}$ ). These values are lower than those reported for Usumacinta levee deposits (2.38-4.55 Gy ka ${ }^{-1}$; Muñoz-Salinas et al., 2016). The difference is likely related to lower amounts of silt and clay in the beach ridges than in the levees. Dose rates are much higher than the extremely low values reported for the quartz-rich beach ridges in Florida (e.g. Otvos, 2005; López and Rink, 2008; Rink and López, 2010).

Quartz OSL ages are internally highly consistent and agree well with the calibrated ${ }^{14} \mathrm{C}$ ages (Figs. 3 and 4), underscoring the usefulness of OSL dating in the establishment of beach-ridge chronologies (Tamura, 2012).

For two samples (450 and 451) collected at the same location but at different depths, OSL ages (respectively $2567 \pm$ 260 and $1957 \pm 210 \mathrm{BCE}$ ) suggested an age difference of about 600 years. A possible partial explanation is that the water content estimations for these samples (field capacity for OSL sample 451; water saturated for sample 450; Table A2) are not correct. If more similar water contents are assumed for both samples, the age difference is greatly reduced, highlighting the importance of water content estimation in OSL dating. An alternative or additional explanation could be that the sediment above the groundwater table was reworked (e.g. through bioturbation). The spread in equivalent dose distribution for sample 179 may indicate such reworking, but for sample 451 the equivalent dose distribution provides no evidence of reworking. For the age-distance model, we excluded OSL ages that were judged to be of questionable validity (179 and 427) and those obtained from sediments above the groundwater table (179 and 451).

The age-distance models for Transects A and B are presented in Fig. 3. For a $3 \mathrm{~km}$ section (Transect A2), the age-distance model was published by Nooren et al. (2017; Fig. 4c). Three new OSL analyses (this paper; Table A2 and Fig. 4c), one providing a questionable age (sample 427), corroborate the robustness of that study. Radiocarbon ages of shells reported by Aguayo et al. (1999) do not provide additional age constraints owing to limitations in the accuracy of the shell ages caused by carbon reservoir effects and taphonomic depositional uncertainty.

We ran a P_sequence Bayesian calibration model $(k=$ $0.05 \mathrm{~m}^{-1}$; Bronk Ramsey, 2009) fed with the AMS ${ }^{14} \mathrm{C}$ and OSL dates and relative shore-normal positions and with boundaries (i.e. discontinuities) prescribed at the transitions between the three main beach-ridge formation phases. For the age-distance model of Transect B (Fig. 3b), we projected AMS ${ }^{14} \mathrm{C}$ and OSL ages of samples from Transect A, correlating along the beach-ridge traces in the lidar data. Because of the assumed time lag between the final burial of leaf fragments in the beach ridges at smaller (Transect A) and greater (Transect B) distance to the river mouth during Phase 2, in the corresponding part of Transect $\mathrm{B}$ the ${ }^{14} \mathrm{C}$ ages of samples 185 and 438 (Fig. 3b) were excluded from the model. We identified one OSL age (sample 437) as an outlier (too old compared to ages of neighbouring samples) and excluded it from the age-distance modelling (Fig. 3b).

The age-distance model for Transect A (Fig. 3a) shows a long-term average progradation rate that decreased from 4.1 to $3.4 \mathrm{~m} \mathrm{yr}^{-1}$ between the start of Phase 2 ( 1800 BCE) and the transition between Phases $3 \mathrm{~A}$ and $3 \mathrm{~B}$ dated at $\sim 1050$ CE. Progradation rates returned to higher values during Phases 3B and 3C, 4.0 and $4.5 \mathrm{myr}^{-1}$ respectively, related to the reconfiguration of the river system and the avulsion of the Usumacinta River around 1050 CE (discussed in Sect. 4.8).

The age-distance model for Transect B (Fig. 3b) includes a preliminary model for Phase 1 (4500-1800 BCE). The model is based on relatively few samples, including OSL ages sensitive to uncertainty related to water content assumptions, and must therefore be treated with caution. The age-distance model for Phase 2 has an age range between $1775 \pm 95 \mathrm{BCE}$ and $30 \pm 95 \mathrm{CE}$ (at $1 \sigma$ ), which covers a slightly shorter time period than Transect A where Phase 2 runs until approximately $150 \mathrm{CE}$. The lidar image shows clear signs of truncated beach ridges between Phases 2 and 3 at Transect B, explaining the occurrence of a hiatus. To investigate possible age-distance scenarios for Transect B 


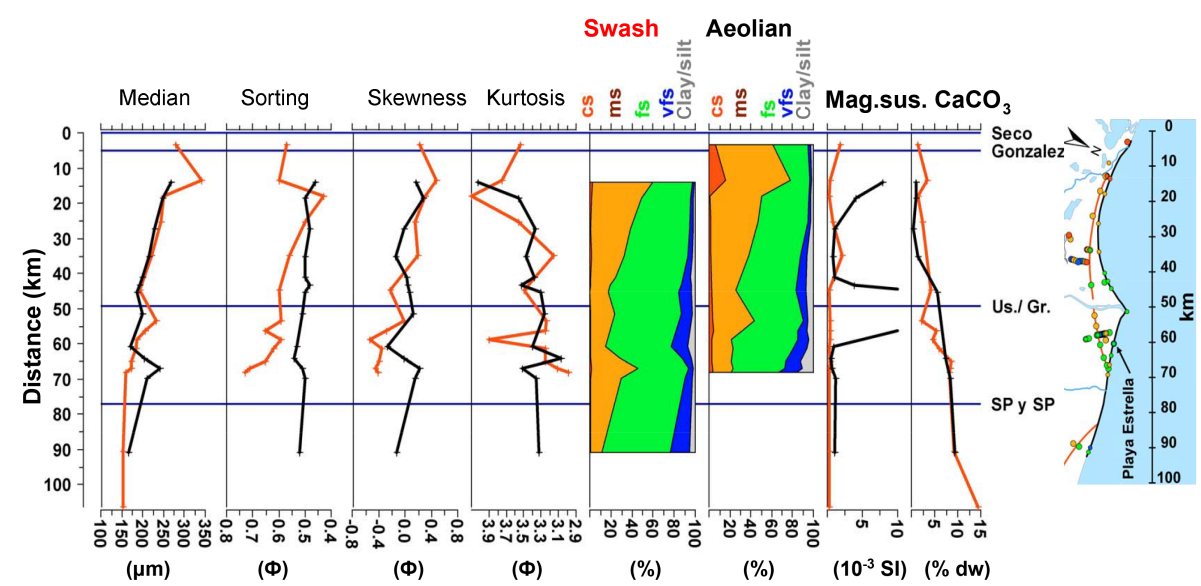

Figure 6. Shore-parallel variability in grain-size parameters of swash (red) and aeolian (black) facies. Vfs: very fine sand; fs: fine sand; ms: medium sand; cs: coarse sand.

(Phase 2), we calculated five possible short- and long-range scenarios (Transect B2-1 to B2-5 in Fig. 2b) by including aeolian accretion (see Sect. 4.7) as a proxy for the progradation rate of the beach-ridge plain. The depicted scenarios (Appendix B, Fig. B2) assume shore-normal aeolian accretion activity to be constant between $1800 \mathrm{BCE}$ and $30 \mathrm{CE}$. Under this assumption the most noticeable change in progradation rate occurred around $1000 \mathrm{BCE}$, during a period when relatively high beach ridges are indicative of a strong drop in progradation rate. This is apparent in both long- and shortrange scenarios and at all five transects. The long-range scenarios seem to be in better agreement with the mean of the OSL ages. These calculations show the potential to improve age-distance models with additional information regarding the temporal variability in aeolian accretion rates.

The age-distance model is less reliable for Phase 3A owing to the lack of dated samples along Transect $B$, the rejection of OSL sample 179, and uncertainties in the projected location of dated samples from Transect A. The age-distance model is very robust again for the period $1050 \mathrm{CE}$ to present (Phases 3B and 3C), with precision of modelled ages of the order of only 10-60 years (at $1 \sigma$ ).

For Transect $\mathrm{C}$ the age-distance model (not shown) is preliminary because it only relies on two AMS ${ }^{14} \mathrm{C}$-dated samples (Table A1) and geomorphological age projections from Transect A.

\subsection{Grain-size analyses}

The beach ridges consist of moderately well-sorted to wellsorted fine to medium sand. Because sediment lithology is very uniform at all core locations and sedimentary microstructures are not recovered in Van der Staay hand corings, core logs are not presented.

All of the 230 analysed sand samples show a unimodal grain-size distribution with a median between 117 and
$350 \mu \mathrm{m}$ (Fig. 5b). The grain size of sand samples from two shore-parallel transects (Fig. 6) shows a general coarsening in the dominant (westward) longshore transport direction.

The longshore trend in grain size is apparent in both swash and aeolian facies (Fig. 6), applies along the full length of the study area, and does not appear to be affected by the deltaic promontory of the Usumacinta and Grijalva rivers in the middle of it. Skewness of the grain-size distribution increases in the dominant longshore transport direction, denoting an increase in excess fines, and the swash facies tend to get better sorted (decrease in phi values) in the same westward direction. Kurtosis values do not show systematic changes. Magnetic susceptibility values also tend to increase in a westward direction, with the most elevated values around the (former) waterline, as heavy minerals, including titanomagnetite, preferentially accumulate in the swash zone (Komar, 2007). The high magnetic susceptibility values for aeolian beachridge sand near the mouth of the currently active Usumacinta, Grijalva, and Gonzalez rivers is likely related to the contribution of volcaniclastic material from El Chichón's 1982 eruption, as magnetite enrichment in the beach-ridge sands also occurred after earlier eruptions of El Chichón (Nooren et al., 2017). The $\mathrm{CaCO}_{3}$ concentration decreases in the longshore transport direction, in line with a decreased influence of calcareous sediment from the calcareous platform in the eastern part of the study area (Ayala-Castanares and GuittiérrezEstrada, 1990; Fig. 1b).

The westward increase in median grain size probably relates to an increase in wave energy, which also may have caused the steepening of the shoreface slopes in that same direction. The presence of mega-cusps at beaches near the mouth of the Gonzalez River is an additional indication of relatively strong wave impact on the western side of the system. Similarly, and at first sight contradictory, grain-size coarsening in the longshore drift direction was observed at St. George Island (Balsillie, 1995) and along the North Sea 

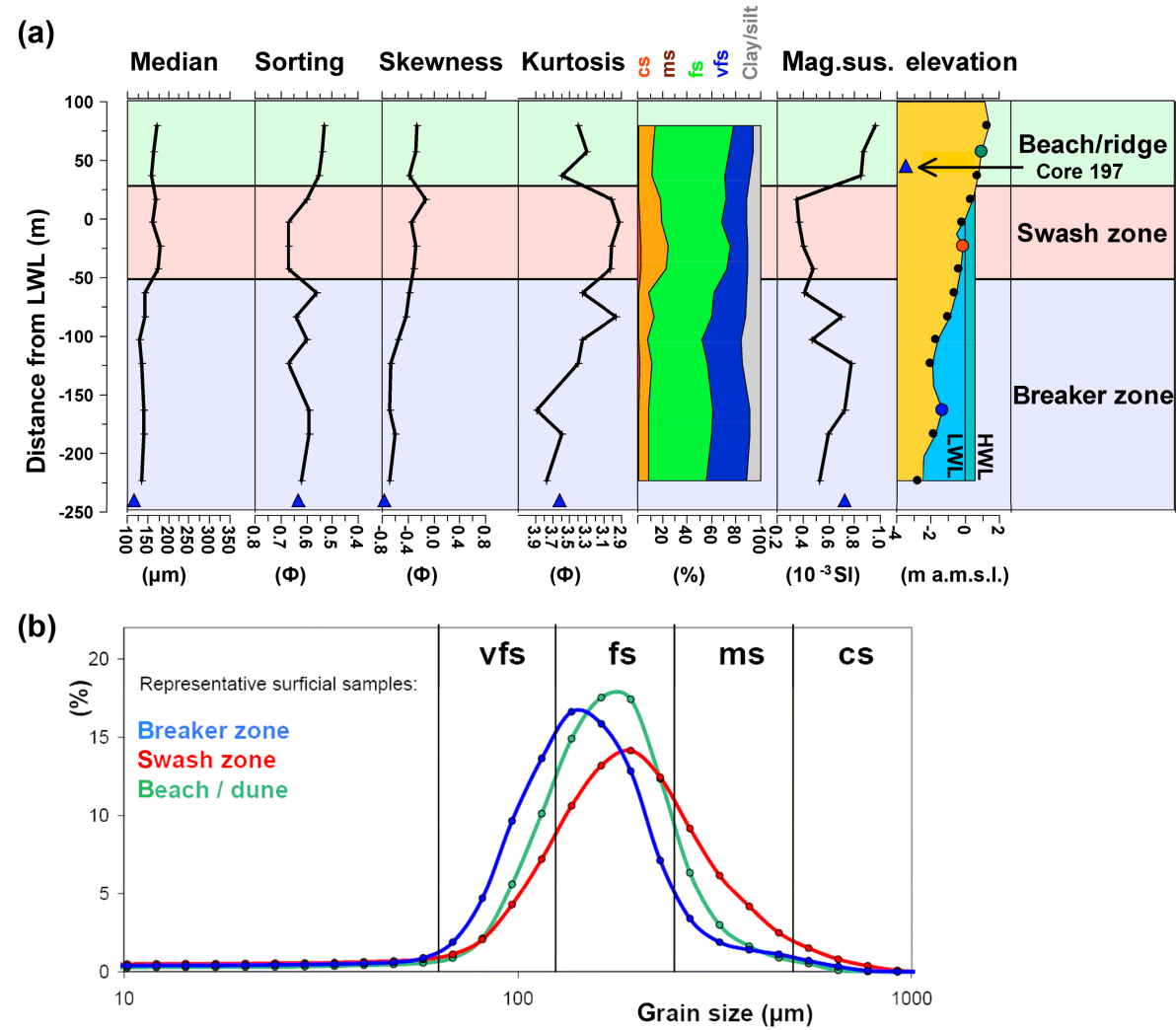

Figure 7. (a) Grain-size variability along a beach-to-nearshore profile of surficial grab samples taken during fair weather conditions in April 2013 at Playa Estrella (see Fig. 6 for location). Sand characteristics of beach core 197 (triangle; sample from -3.5 ma.m.s.1.) taken in 2012 at the same location are shown for comparison. The sand sample likely had its origin in the nearshore region at a distance of $240-300 \mathrm{~m}$ from the contemporary low-tide line (here shown at $240 \mathrm{~m}$ ), assuming a comparable beach profile during time of deposition. LWL and HWL are mean low and high water level; (b) grain-size distribution of representative surficial sand samples from the beach profile denoted by coloured circles in Fig. 7a.

beaches of East Anglia, England (McCave, 1978). McCave (1978) explained the coarsening of beach sand in the longshore transport direction as a result of the winnowing of fines and their offshore transport by tidal currents. Similar processes could be responsible for the westward grainsize coarsening and could explain the dominance of relatively fine clastic sediments on the continental shelf at the study site (Ayala-Castanares and Guittiérrez-Estrada, 1990; Fig. 1b). The offshore transport of fines is probably stimulated by the anticyclonic eddy that develops during spring and moves westward along the coast during summer (Salas de León et al., 2008). This eddy influences bottom currents, especially west of the Usumacinta-Grijalva outlet. Lastly, it should be noted that deviations from this general pattern in longshore grain-size distribution do occur. The relatively coarser grain size of the three aeolian samples approximately $10 \mathrm{~km}$ west of the SP y SP River, for example, are probably due to the contribution of eroded and reworked sand from the old promontory of the SP y SP River (Fig. 6).

Although the major variability in grain-size parameters occurs in a shore-parallel direction, shore-normal sorting pro- cesses due to wind and wave activity have resulted in significant variation in grain-size parameters as well (Fig. 7). Surface samples from the modern beach profile at Playa Estrella (Fig. 7a) show an increase in grain size from offshore towards the coast, with coarsest and least sorted sand occurring in the relatively high-energy swash zone. The grain-size characteristics of backshore beach deposits and dune or ridge sands are very similar. They differ from the swash deposits in having a reduced presence of coarse grains (more symmetrically skewed) and a better sorting (Figs. 7 and B4). These properties indicate that aeolian processes have likely been in play in the development of backshore deposits and dune ridges.

The grain-size variability in the shore-normal direction along Transect A (Appendix B, Fig. B3) is very similar to that of surficial samples taken at the current beach at Playa Estrella. Samples from core 197 (Fig. B3, 0.04 km) reflect shore-normal sorting processes and demonstrate a coarsening upward sequence with strongly negatively skewed relatively fine sandy deposits at -4 ma.m.s.l., likely deposited in the nearshore zone (Fig. 7a). These deposits are covered 


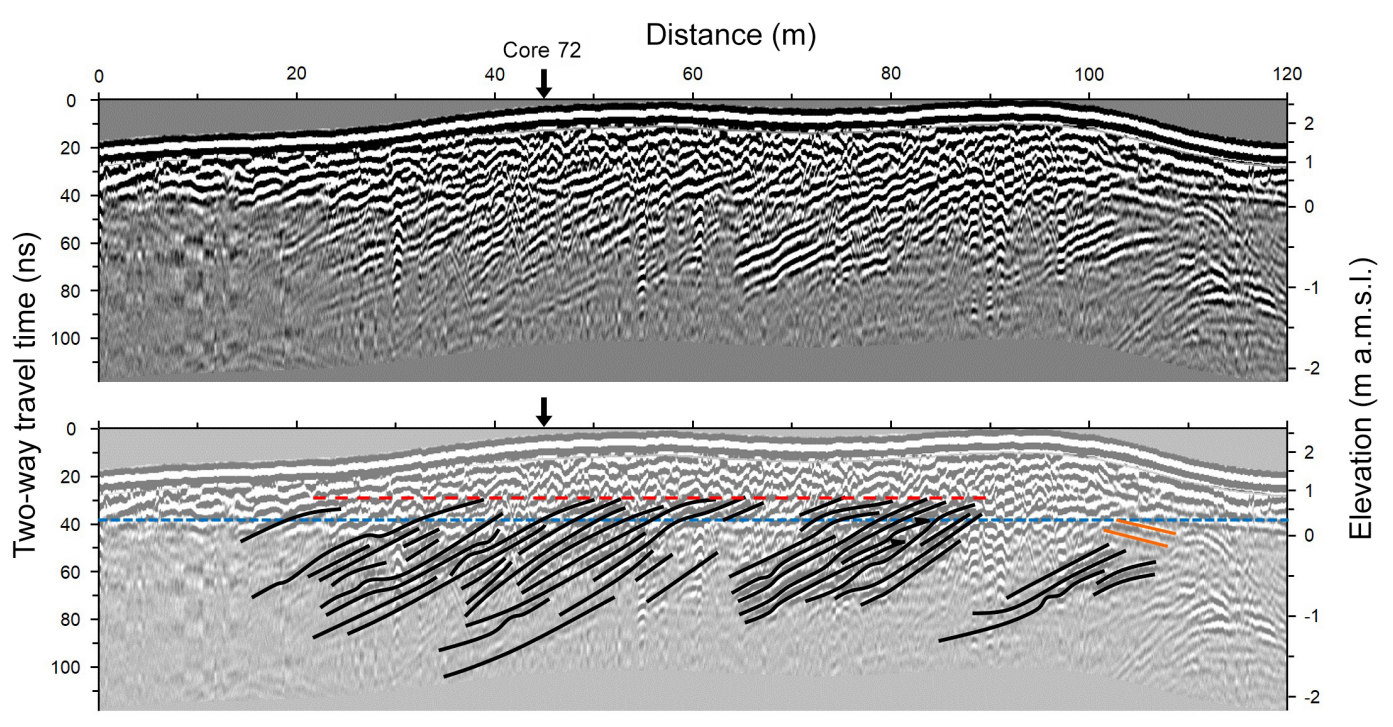

Figure 8. Processed GPR data and interpretation for two closely spaced relatively elevated beach ridges along Transect A (see Figs. 2 a and 3a for location). Time-to-depth conversion for the elevation axis was based on velocities of 0.125 and $0.06 \mathrm{mns}^{-1}$ above and below the water table, respectively. The position of the water table at $0.2 \mathrm{ma}$.m.s.l. (blue dashed line) was drawn on the basis of changes in reflection characteristics and confirmed by observations from core 72 (black arrow). Here, the water table was positioned at $2.2 \mathrm{~m}$ below the land surface. Highlighted in the interpretation are foreshore and shoreface deposits (black dipping lines) and the transition from foreshore to backshore and/or aeolian deposits at $0.8 \mathrm{~m}$ a.m.s.l. (red dashed line). Also shown are reflection terminations (black half arrows) indicating possible bar welding and some landward-dipping structures (orange lines) possibly related to infill of a large former runnel. The curved reflections around $110 \mathrm{~m}$ (40 ns and deeper) are caused by surface scattering off a large nearby tree that was passed while moving the GPR along the transect.

by a few metres of fine sand with grain-size parameters resembling the surficial samples from the swash zone (Fig. 7a), which is consistent with Walther's Law.

Samples from beach ridges formed during Phase 3B (Figs. 4b, B3, and B4) are strikingly different from the general pattern (Fig. 7b), with a higher contribution of wellsorted fine to medium sand likely related to increased availability of reworked sand due to the erosion of the SP y SP promontory. The same process is likely responsible for the coarser grain sizes of the aeolian sand samples from the youngest ridge collected $10 \mathrm{~km}$ west of the still eroding SP y SP promontory (Fig. 6).

\subsection{Internal architecture}

Despite the high signal attenuation, which limited the depth of investigation in various areas, the GPR measurements clearly show strong seaward-dipping reflectors in all transects (Fig. 8) with slopes between 2 and $5^{\circ}$ (Figs. $4 \mathrm{~b}$ and 8). Since all GPR transects were oriented perpendicular to the ridges, these angles are close to the actual angles. The values are similar to dipping angles reported by Psuty (1967) for beach deposits elsewhere along this coast. The largest slope angles are preferentially associated with more elevated beach ridges. No reflections hinting at interrupting erosional surfaces are apparent, and strong landward-dipping reflectors were rarely encountered in the GPR-surveyed transects.
The top of the foreshore deposits is located around $0.8 \mathrm{~m}$ a.m.s.l. (Fig. 8). At depths between 1 and $2 \mathrm{~m}$ a.m.s.l., the slopes of the upper shoreface deposits start to decrease. Reflection terminations (e.g. at $x=82 \mathrm{~m}$ and $y=40-50 \mathrm{~ns}$ in Fig. 8) suggest the periodic welding of bars onto the beach face. This mechanism of beach progradation by accretion of longshore bars is typically associated with a large sediment supply and longshore sediment transport (e.g. FitzGerald et al., 2000; Aagaard et al., 2004; Tamura, 2012). Unrelated to this bar welding event, the GPR profile shows a few landward-dipping reflections at the top of the beach sequence (at $x=100-110 \mathrm{~m}$ and $y=40-50 \mathrm{~ns}$ in Fig. 8) that may be associated with the infill of a large runnel that formed when a swash bar merged with the beach.

The GPR results compare well with the extensive investigations conducted at the fine sandy swash-built beach ridges at St. Vincent Island, Florida (Forrest, 2007), confirming the prominence of swash deposits in beach-ridge sequences formed under microtidal conditions and relatively low wave impact. It is hard to distinguish the aeolian radar facies from those of the lithologically similar beach deposits, with the only useful indicator being the termination of seawarddipping foreshore reflections (red dashed line in Fig. 8). The absence of significant internal erosional surfaces suggests that the ridges formed quickly or at least continuously, uninterrupted by significant coastal erosion events. Landward- 
dipping overwash deposits, as described by Psuty (1967, 1969), are not evident in our selected GPR transects (nor did lidar data support their presence in the promontory parts of the beach-ridge complexes). The landward-dipping structures in Fig. 8 are situated too deep in the subsurface to be interpreted as overwash deposits.

\subsection{Composition and source of beach-ridge sands}

The major-element compositions of relatively large sandsized volcanic glass shards and pumice fragments $(250$ $1500 \mu \mathrm{m})$ and a pumice clast of $1.5 \mathrm{~cm}$, isolated from beachridge samples along Transect A, are reported in Table A3. The major-element composition is similar to that of the Late Pleistocene Los Chocoyos tephra (Kutterolf et al., 2008) and is significantly different from any of the late Holocene tephras of the El Chichón volcano (Fig. 9; Nooren et al., 2017). It is therefore inferred that Los Chocoyos ignimbrites have been an important sediment source for the UsumacintaGrijalva delta. They were emplaced during a mega-eruption at the Atitlán volcanic centre around 84000 years ago (Drexler et al., 1980), which produced an estimated 150 to $160 \mathrm{~km}^{3}$ dense rock equivalent (DRE) of tephra fall and some $120 \mathrm{~km}^{3}$ DRE of pyroclastic flow deposits (Rose et al., 1987). It is the only Late Pleistocene volcanic eruption that deposited voluminous tephra north of the Motagua River valley (Fig. 1a; Koch and McLean, 1975). The Los Chocoyos pyroclastic flow deposits reach thicknesses of more than $200 \mathrm{~m}$ and have been found well into the watersheds of the Grijalva and Usumacinta rivers (Instituto Geográfico Nacional, 1970; Koch and McLean, 1975; Rose et al., 1987; Sánchez-Núñez et al., 2015). We estimate that approximately 3 and $16 \%$ of the pyroclastic flow deposits were deposited in the Grijalva and Usumacinta watersheds, respectively. In the steep and poorly vegetated terrain, these volcaniclastic deposits are vulnerable to erosion and particularly prone to mass transport by landslides (Harp et al., 1981). It is therefore not surprising that abundant volcaniclastic minerals and glass shards (Solís-Castillo et al., 2013) were found in Holocene levee deposits of the Usumacinta River at Tierra Blanca (Fig. 1a), reflecting reworked Los Chocoyos tephra as geochemical and micromorphological evidence suggests (Table A3, Cabadas-Báez et al., 2017).

The heavy mineral analyses confirm the presence of volcaniclastic material within the beach-ridge sands. The nonopaque heavy minerals are dominated by green and brown amphiboles, clinopyroxene, titanite, and epidote, whereas the opaque heavy minerals are dominated by titanomagnetite.

\subsection{Beach-ridge elevation}

The temporal variability in beach-ridge elevation along the fifteen cross-normal ribbon-shaped elevation transects representing Phases 2 and 3 is demonstrated in Fig. 10. Most noticeable are the high-amplitude elevation changes along

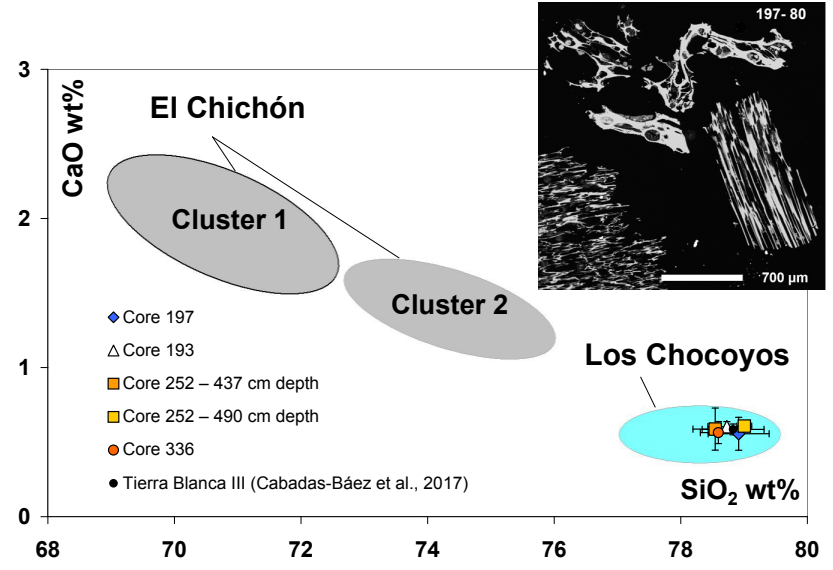

Figure 9. $\mathrm{SiO}_{2}-\mathrm{CaO}$ diagram for analysed volcanic glass shards plotted along with compositional characteristics of El Chichón (Nooren et al., 2017) and Los Chocoyos tephra (Kutterolf et al., 2008). Data points represent averages for 5-12 particles (bars are $1 \sigma)$. The $\mathrm{SiO}_{2}-\mathrm{CaO}$ composition of volcanic glass shards recovered from Usumacinta levee deposits at Tierra Blanca III (Cabadas-Báez et al., 2017) are indicated for comparison. We refer to Table A3 for all major-element data. Inset: thin section of pumice and volcanic glass shards recovered from the beach-ridge sands (core 197; sample from $80 \mathrm{~cm}$ below the surface). Notice the elongated vesicularity of one of the pumice fragments.

Transect B during Phase 2 and the relatively low SDs during periods in which elevated beach ridges were formed. Although swale elevations should preferably not be used as sea level index points for the reconstruction of relative sea level (RSL) rise, overall, mean swale elevations along Transects $\mathrm{A}, \mathrm{B}$, and $\mathrm{C}$ show a continuously increasing trend of about $0.3 \mathrm{~mm} \mathrm{yr}^{-1}$ (Fig. 10). This is in line with the expected longterm rate of RSL rise in the southern Gulf of Mexico area and comparable to that of the reconstruction of RSL rise made by Gischler and Hudson (2004) for Belize. The estimated depths of pedogenic decalcification (Fig. 3a and b) also support this RSL curve, but further analyses are needed for better refinement. We found no evidence for a mid-Holocene RSL high-stand followed by a $2 \mathrm{~m}$ drop during the late Holocene (e.g. Stapor et al., 1991; Tanner, 1992; Morton et al., 2000; Blum et al., 2003). Rather, our observations are in accord with more recent RSL reconstructions for the northern Gulf of Mexico coast that show a gradual rate of RSL rise during the late Holocene (Törnqvist et al., 2004; Milliken et al., 2008; Donelly and Giosan, 2008).

\subsection{Volumetric growth rate of the beach-ridge plain}

The total average late Holocene sediment accumulation rate was estimated by simply dividing the total volume of beach-ridge deposits along the system's $150 \mathrm{~km}$ length by the duration of beach-ridge formation. Assuming an average thickness of $10 \pm 2 \mathrm{~m}$, the overall average accumulation 

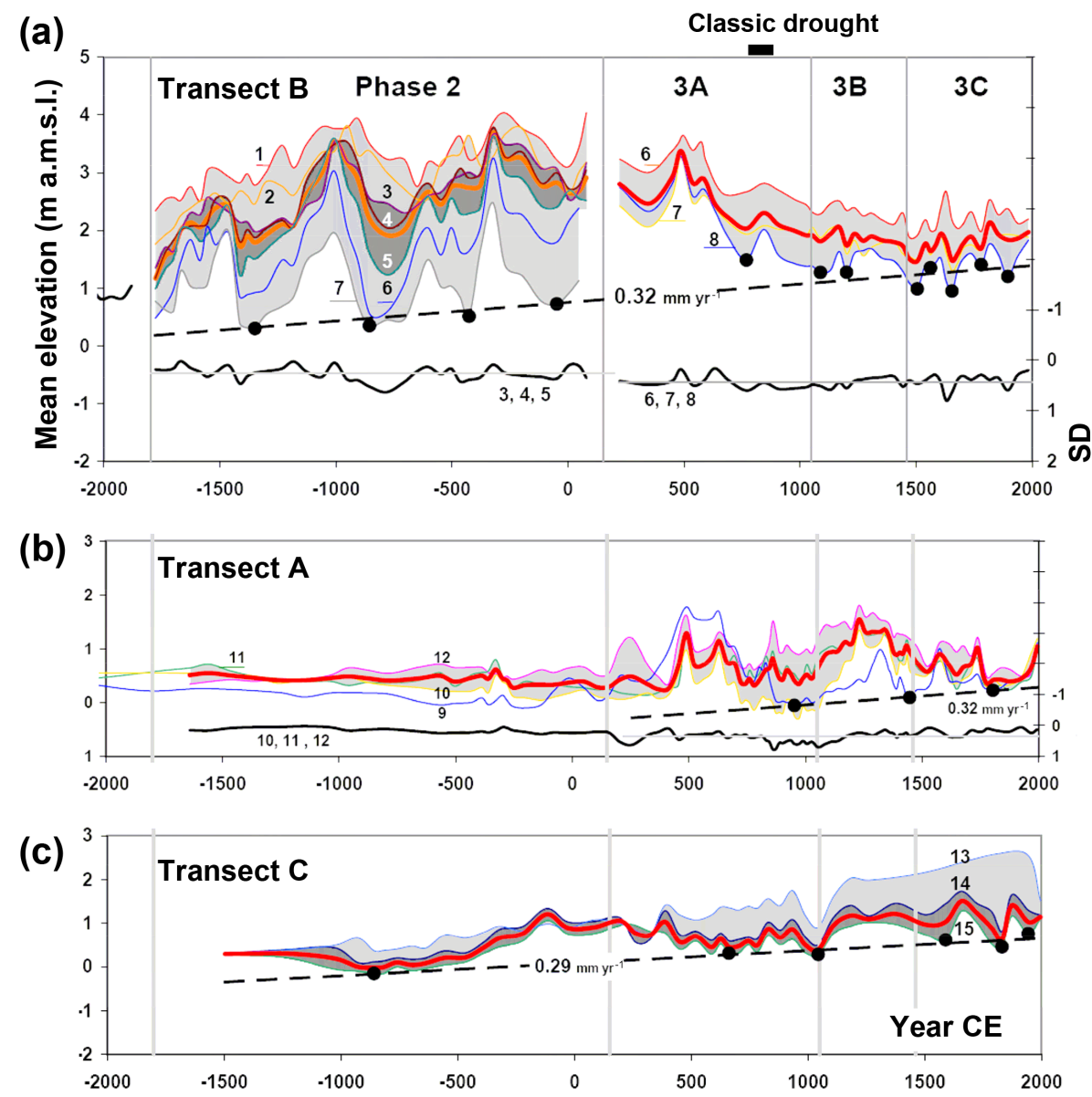

Figure 10. Mean beach-ridge elevation variability along shore-normal Transects B (a), A (b), and C (c). See Fig. 11a for the location of the individual transects. Notice the relatively high beach-ridge elevations around 800-950 CE for all three transects. This period is known for the occurrence of multiple prolonged droughts and has been related to the Classic Maya collapse.

rate over the period $1800 \mathrm{BCE}$ until today has been $2.3-$ 3.5 million $\mathrm{m}^{3} \mathrm{yr}^{-1}$. Accumulation rates along Transects A, $\mathrm{B}$, and $\mathrm{C}$ range between 16 and $54 \mathrm{~m}^{3} \mathrm{~m}^{-1} \mathrm{yr}^{-1}$ (Table 2).

The calculated average accumulation rate is exceptionally high compared to that reported for other large beachridge systems, such as 0.05 million $\mathrm{m}^{3} \mathrm{yr}^{-1}$ at Guichen Bay, Australia (Bristow and Pucilllo, 2006), 0.14 million $\mathrm{m}^{3} \mathrm{yr}^{-1}$ at Keppel Bay, Australia (Brooke et al., 2008a), and 1.7 million $\mathrm{m}^{3} \mathrm{yr}^{-1}$ at Kujukuri, Japan (Tamura et al., 2010). As these systems are much shorter than the UsumacintaGrijalva plain, accumulation rates are more similar when expressed in $\mathrm{m}^{3} \mathrm{~m}^{-1} \mathrm{yr}^{-1}$. For two other large beachridge systems with detailed chronological control, we estimate accumulation rates of 0.92 million $\mathrm{m}^{3} \mathrm{yr}^{-1}$ (Nayarit, Mexico; using cross sections in Curray et al., 1969) and 1.4 million $\mathrm{m}^{3} \mathrm{yr}^{-1}$ (Katwijk, the Netherlands; using sections in Cleveringa, 2000).

Average aeolian accretion rates along Transects A, B, and $\mathrm{C}$ range between $1.5 \pm 1.0$ and $6.6 \pm 1.9 \mathrm{~m}^{3} \mathrm{~m}^{-1} \mathrm{yr}^{-1}$ (Table 2), with relatively high values along Transect B dur- ing Phase 2 and along Transect A during Phase 3B. Rates are much higher than the average long-term aeolian accretion rates of $0.1-0.6 \mathrm{~m}^{3} \mathrm{~m}^{-1} \mathrm{yr}^{-1}$ for three beach-ridge plains in south-eastern Australia (Oliver, 2016) but are relative low compared to average long-term accretion rates for larger-scale foredunes, which roughly vary between 5 and $20 \mathrm{~m}^{3} \mathrm{~m}^{-1} \mathrm{yr}^{-1}$ (e.g. Aagaard et al., 2004; Ollerhead et al., 2013; Keijsers et al., 2014).

Aeolian accretion rates are ca. 6-26\% of the total volumetric growth rate of the beach-ridge plain (Table 2), comparable to the $10.5 \%$ inferred for the Moruya beach plain, Australia (Oliver, 2016). Aeolian processes therefore play a minor role in beach-plain sediment accretion.

We found a relatively large contribution of aeolian accretion ( $26 \pm 10 \%$ of total beach-ridge accretion) for beach ridges formed along Transect $\mathrm{B}$ between approximately $1800 \mathrm{BCE}$ and $30 \mathrm{CE}$ (Phase 2), which could be an indication of stronger north-easterly winds during this time. 


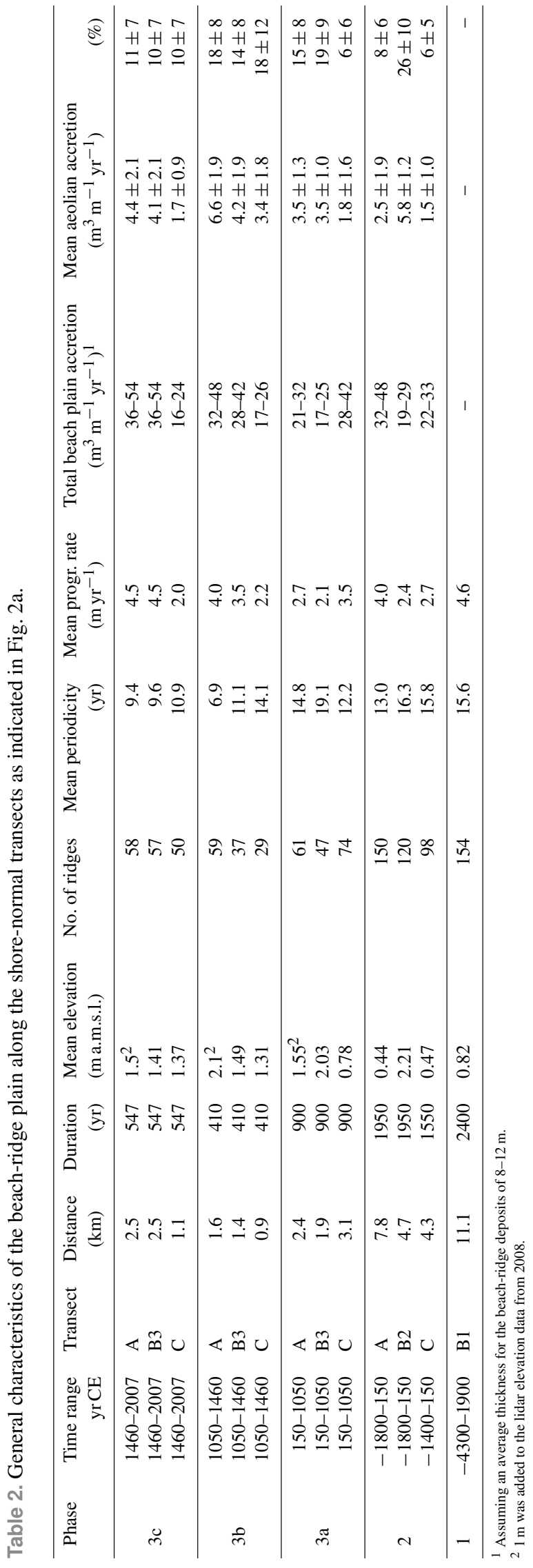

\subsection{Evolution of the beach-ridge plain}

The new chronological, geomorphological, and sedimentary data enabled us to reconstruct the three-phased development of the beach-ridge complex in considerably more detail than previous researchers.

The oldest part of the beach-ridge sequence (Phase 1) has been almost completely preserved on the inland side of the barrier complex south-west of the current confluence of the Grijalva and Usumacinta rivers (Tres Brazos, Fig. 2b). Here, beach ridges are partly covered by organic-rich backbarrier marsh deposits that locally reach thicknesses of up to $4 \mathrm{~m}$ (e.g. core 307; Fig. 2b). To the east of Tres Brazos (Fig. 2b), no Phase 1 beach-ridge topography is discernible from the DEM. Any Phase 1 ridges were likely eroded over time by the migrating Usumacinta River. Our oldest age of $4248 \pm 90$ BCE (at $1 \sigma$ ) for freshwater organic deposits (sampled in core 307; Fig. 3b), post-dates the onset of coastal progradation in the study area. This organic unit formed after the oldest beach ridges had developed, suggesting that the inception of the Usumacinta-Grijalva beach-ridge plain (i.e. the onset of Phase 1), marking the transition from transgressive to regressive conditions, probably occurred centuries earlier (ca. 4500 BCE).

Relatively coarse-grained beach ridges, inferred to be supplied with sediment by a branch of the Grijalva River, accreted during Phase 1A along the inland part of Transect B (Fig. 5a). This set of beach ridges formed until $2800 \mathrm{BCE}$ at a time when RSL was several metres lower than today. Nowadays, only the most elevated beach ridges formed during that phase protrude from the marshy plain.

During Phase 1B, which lasted until $1800 \mathrm{BCE}$, the Usumacinta River system increasingly supplied relatively fine sediment to the area as its SP y SP distributary developed. The inland part of Transect A shows that the new promontory at the mouth of the SP y SP did not immediately develop the characteristics of a mature beach-ridge plain. At core location PP1 and at Pozpetr (Fig. 3a), only clayey estuarine and organic flood basin deposits occur. The first beach-ridge sand body only starts near core 336 . The few linear structures in the DEM that are discernible further inland may represent chenier-like features (as tentatively indicated in Fig. 3a). The Grijalva River system continued to influence beach-ridge formation in the area of Transect B. During Phase 1B it made use of the "Popal Grande palaeochannel" (Psuty, 1967), which was active between approximately 2800 and 2100 BCE (Fig. 5).

During Phase 2 (1800 BCE-150 CE), the SP y SP promontory further developed. Its relative large acute angles between beach ridges and the present-day coastline (Fig. 2) indicate that riverine sediment supply contributed significantly to the growing beach-ridge complex. Fluvial contributions from more easterly sources are improbable because sizeable rivers have not been present east of the SP y SP branch. In addition, calcareous biogenic sediments dominate in that 
sector of the coastal lagoonal plain, particularly east of Ciudad del Carmen (Fig. 1b). A marine source area is unlikely as well because surface sediments in front of the SP y SP river mouth are predominantly composed of clay and fine silt (Ayala-Castañares and Guttiérrez-Estrada, 1990). A possible marine source area for beach-ridge sands is the seabed in the western part of the study area (Fig. 1b), but there is no known mechanism that could have moved vast amounts of sediment against the dominant drift direction. A terrestrial contribution via longshore current, sourced from the Grijalva River mouth, is unlikely for the same reason: the necessary transport path would be opposite to the dominant drift direction. Moreover, the main distributaries of the Grijalva River system at the time were positioned farther westward than at present (e.g. the Pajonal and Blasillo palaeodistributaries described by Von Nagy, 2003; Fig. 1b). Towards the end of Phase 2, a slight increase in acute angles of the beach ridges is seen about $5 \mathrm{~km}$ west of the present main outlet (Fig. 2a). This local anomaly from the overall pattern indicates temporal activation of a distributary river mouth at this location, which may be seen as a precursor of the nearby main outlet active during Phase 3.

The transition between Phases 2 and 3 is set at regionally truncated beach ridges in the area near Transect B. These features indicate a major reorganisation in the Grijalva and Usumacinta distributary network and river mouths. Around $150 \mathrm{CE}$, a new major delta promontory began to develop that still is the joint outlet of the Grijalva and Usumacinta rivers today. In its development, we distinguish three subphases. During Phase 3A, the old SP y SP outlet was still functioning. At the end of Phase 3A, the Usumacinta had fully avulsed towards its current location, terminating sediment delivery at the old outlet. The age-distance model of Transect A2 (Fig. 4c) indicates that this latter avulsion occurred around 1050 CE. The break between Phases 3A and B is marked by a shift in beach-ridge orientations. West of the SP y SP abandoned outlet, elevated beach ridges are related to increased sediment supply due to cannibalisation of the former promontory. Even today, the old SP y SP promontory is still eroding, with current rates around $3.5 \mathrm{myr}^{-1}$ (OrtizPérez, 1992; Ortiz-Pérez et al., 2010).

The transition between Phases 3B and 3C, placed at $1460 \mathrm{CE}$, is not related to river outlet repositioning and therefore morphometrically more arbitrary. It is reflected by moderate increases in progradation rate (Table 2).

\section{Discussion}

\subsection{Beach-ridge-formation model}

Psuty $(1965,1967)$ suggested an important contribution of storm surges and related overwash to the development of the Usumacinta-Grijalva beach ridges. Our GPR measurements revealed only evidence for swash-built beach ridges with an aeolian cap on top, whereas typical landward-dipping reflec- tions from washovers have not been identified. In addition, the sandy deposits do not include any exceptionally coarse sand layers within the upper part of the cores, and most of the analysed sand samples from a.m.s.l. were characterised as aeolian in origin. The DEM of the area shows little evidence of extreme storm events impacting the area; scour holes were only identified along one beach ridge, formed around 1450 CE. Nevertheless, storms do play a role in beach-ridge formation. Strong north-westerly winds during "Nortes", for example, cause beach erosion (West et al., 1969). Owing to a temporal reversal in the longshore current direction, sand is transported eastward and contributes to beach-ridge formation in the eastern part of the study area. Individual storms associated with the nearby passage of hurricanes will also lead to beach erosion. In both cases foreshore recovery likely takes places within a few months after the erosional event (Carter, 1986 and references therein).

The GPR data show that each beach ridge in the study area likely starts as a wave-built swash bar, formed over a period of 7-19 years. Once stabilised and no longer subject to hydrodynamic processes, subsequent wind processes create an aeolian cap on the ridge. Sand is blown in from the adjacent beach, including the active intertidal swash bar (exposed during low tide). It is trapped by pioneer vegetation, especially Ipomoea pes-caprae, that rapidly colonises the young ridge. The final ridge elevation is determined by the length of the period that the ridge is located next to the beach: the longer the ridge is exposed to aeolian sand deposition, the higher it becomes, which is also found at other coastal sites (e.g. Shepherd, 1991; cited by Tamura, 2012). Consequently, high beach ridges arise when the coastal propagation rate is low. Along individual beach ridges, sections formed relatively close to an active river apex, where progradation rates are high (Fig. 11b), are lower than those formed farther away (Fig. 11c), where progradation rates are low. Apparently, reduced sediment supply leads to higher ridges.

\subsection{Beach-ridge elevation as a proxy of riverine sediment supply}

Beach-ridge elevation is negatively correlated with progradation rate, both in shore-normal (Transect A, Phase 3A; Fig. 4c) and in a longshore direction (Fig. 11c). For periods when rivers supplied most of the sediment stored in the beach-ridge system, we hypothesise that ridge elevation along shore-normal transects may be used as a proxy for fluvial sediment supply through time and space. Owing to the large storage capacity within the river basin, sediment availability for fluvial transport is not a limiting factor. Peak river discharge events and extended periods of large supply translate into high progradation rates and lower ridges. Periods of reduced supply during dry conditions, when rivers are less capable of transporting large amounts of sand, result in higher ridges. Evidence for our hypothesis is provided by a comparison of the beach-ridge morphology with inde- 
(a)
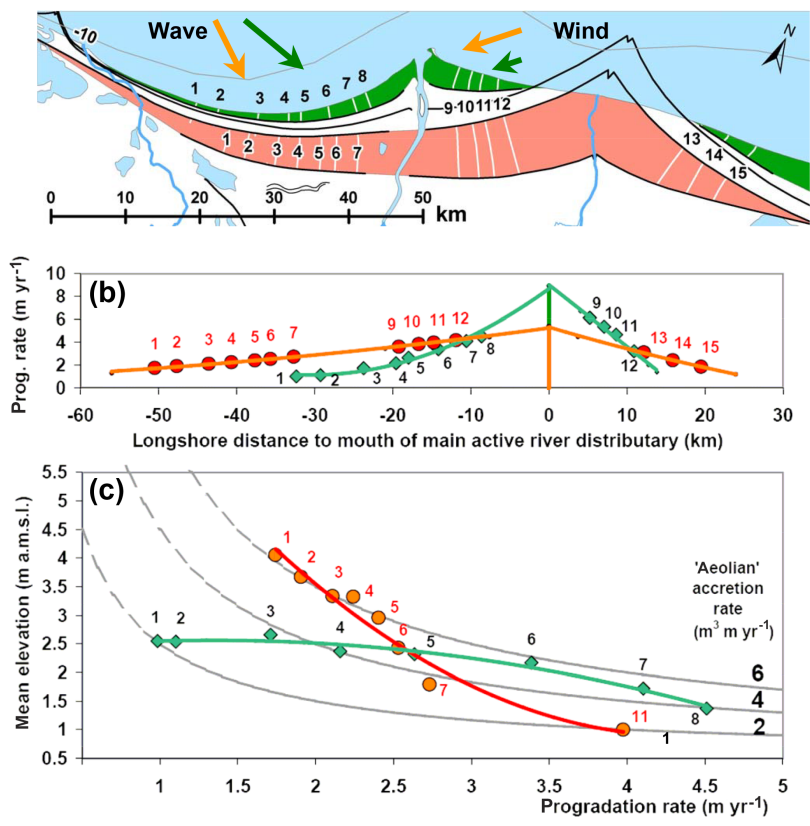

Figure 11. Variability in shore-parallel beach-plain progradation rate (b) and mean elevation (c) for Phase 2 (1800 BCE-150 CE; orange and red) and Phase 3C (1460-1965 CE; green). Dashed lines represent calculated elevation values for constant aeolian accretion rates. Arrows in panel (a) indicate the estimated dominant direction of swell driving the formation of the swash deposits and the dominant wind direction related to aeolian sand transport responsible for the formation of an aeolian cap on top of the swash-built beach ridges.

pendent information on climate in the catchments. During phase $3 \mathrm{~A}$, relatively high beach ridges were formed along Transects $\mathrm{A}, \mathrm{B}$, and $\mathrm{C}$ during the period between 810 and 950 CE (Fig. 10). This period, associated with the Classic Maya collapse, is well known for the occurrence of multiple prolonged droughts in southern Mexico (Hodell et al., 1995) and Guatemala (Wahl et al., 2014).

Direct sediment supply by rivers, however, is not always the main driver in coastal progradation. Cannibalisation of abandoned promontories may generate abundant sandy sediment for anomalously high sediment supply along the downdrift beach. A drastic increase in sediment supply due to the erosion of the SP y SP promontory after the avulsion of the Usumacinta River around 1050 CE resulted in increased availability of sand for aeolian reworking, triggering the formation of relatively high beach ridges on both sites of the eroding SP y SP promontory (Figs. $4 \mathrm{~b}$ and 10). Even $\sim 1000$ years after the avulsion that caused the Usumacinta River to join the Grijalva River at Tres Brazos, coastal erosion at its former SP y SP apex is still ongoing. This process is obscuring the relationship between direct fluvial sediment supply and beach-ridge elevation but can be recognised as a separate force because it caused major changes in the ge- ometry and orientation of beach ridges (Fig. 2a) and clear changes in grain-size characteristics (Figs. $4 b$ and $5 b$ ).

Detecting changes in fluvial sediment supply from beachridge elevation differences requires that there are no major changes in wave and wind climate affecting the signal. Such changes in wave and wind climate should be reflected in significant changes in the granulometric parameters of the deposited beach-ridge sand. After normalising for the effects of new river mouth initiation and old promontory abandonment, we find only minor remaining granulometric differences in our study area. Comparison of modern deposits to the fossil beach deposits of Transect A (Fig. B3) suggests that wind and wave climate (multi-decadal averaged) during the past 2000 years (Phase 3) have been comparable to those of the present. In contrast, the different geometry of the beach-ridge plain formed during the earlier Phase 2 (Fig. 11a) indicates that wind and wave climate at that time were likely different from the situation today. During Phase 2, progradation rates decreased relatively slowly with increasing distances from the SP y SP River mouth (Fig. 11b), and the promontory seems less asymmetric than the promontory formed during Phase 3C at the joint outlet of the Usumacinta and Grijalva rivers. This difference can be explained by a higher contribution of high-angle waves from the west in the construction of the delta promontory, especially over the past 500 years, which is in agreement with model simulations of delta development near river outlets (Ashton and Giosan, 2011). Such geometric changes can thus occur without changes in sediment supply.

We speculate that the increased contribution of high-angle waves during Phase 3 is a possible response to the increasingly frequent occurrences of north-westerly winds, probably related to a stronger and more frequent contribution of cold fronts than before. During Phase 2, the Intertropical Convergence Zone (ITCZ) was farther northward and likely associated with stronger north-easterly winds that could have caused the westward increase in aeolian accretion rates during this time period (Fig. 11c).

\subsection{Beach-ridge periodicity}

Combining the age-distance modelling with the lidarderived beach-ridge morphometrics (Fig. 2a), it is evident that the development of past ridge-swale couplets took between 7 and 19 years (Table 2) and that the time interval for the formation of subsequent ridge-swale couplets decreased with increasing progradation rate (Table 2). This relationship is apparent not only in shore-normal transects marked by variable progradation rates, but also in a shore-parallel direction with beach ridges merging away from the river mouth supplying the sediment. It corroborates a similar finding of Thompson (1992) for Lake Michigan beach ridges and indicates that an allogenic cause of individual beach-ridge formation (e.g. periodic decimetre-scale lunar or steric sea level oscillations; Tanner, 1995) is unlikely. In this light, it 
should be noted that long time series of water level data from seven tide gauges along the southern Gulf of Mexico (Salasde-León et al., 2006) do not show any decadal periodicity. The inter-annual amplitude variability is only a few centimetres, an order of magnitude lower than the intra-annual amplitude range of $25 \mathrm{~cm}$ between a February low and an October high. We therefore conclude that ridge-swale couplets at the study site are not formed in response to RSL oscillations. This finding agrees with the findings of Tamura (2012) and Moore et al. (2016) that the formation of individual ridge-swale couplets is driven by autocyclic processes (Moore et al., 2016). Comparison with periodicities reported from other large beach-ridge systems (Fig. 12) indicates that low periodicities $(<25$ years) are indeed generally found at sites with high progradation rates $\left(>1.5 \mathrm{~m} \mathrm{yr}^{-1}\right)$.

\section{Conclusions}

Our study demonstrates the importance of riverine sediment supply in the formation of the Usumacinta-Grijalva beach-ridge sequence, corroborating earlier geomorphological studies (Psuty, 1965, 1967; West et al., 1969). In contrast to this earlier work, we propose a mechanism of ridge formation without a significant role of storm surges and overwash deposits. The fine sandy beach ridges were mainly swash built, have an aeolian cap, and likely formed under fair weather conditions without the requirement of sea level oscillation. Autocyclic processes controlled the periodicity (7-19 years) in beach-ridge formation. The relatively low periodicities are related to high progradation rates $(>\sim$ $1.5 \mathrm{~m} \mathrm{yr}^{-1}$ ) and reflect ample sediment supply. The indicative meaning of beach-ridge periodicities in palaeoenvironmental reconstructions is limited.

We estimate that sediment supply, distributed along $150 \mathrm{~km}$ of coastline, was roughly $2.3-3.5$ million $\mathrm{m}^{3} \mathrm{yr}^{-1}$, which is exceptionally large compared to that of other large beach-ridge sequences. This can be attributed to extensive availability of easily erodible Los Chocoyos ignimbrites in the headwater catchments of the Usumacinta River given the abundance of fragmented volcanic material derived from this unit in the beach-ridge sands.

Our observations enabled us to subdivide the three main phases in the development of the beach-ridge plain (Psuty, 1965, 1967; West et al., 1969) further into six subunits related to changes in the configuration of the main river distributaries of the Usumacinta and Grijalva river system. Combined ${ }^{14} \mathrm{C}$ and OLS dating provided a robust and consistent chronological framework for these phases, which substantially improved the existing chronology based on radiocarbon-dated shell material (Aguayo et al., 1999).

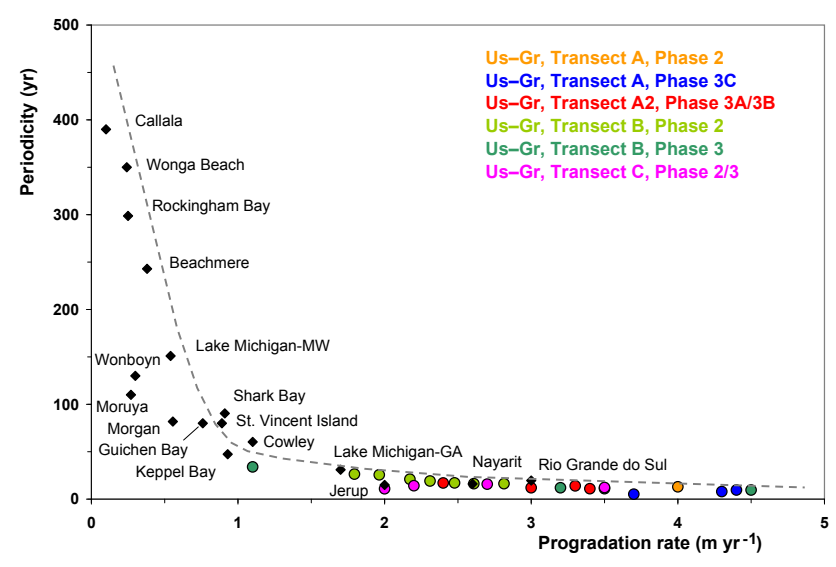

Figure 12. Periodicities of beach-ridge formation for the Usumacinta-Grijalva (Us-Gr) system compared with reported or estimated values for other large beach-ridge systems: Rockingham Bay (Forsyth et al., 2010), Beachmere (Brooke et al., 2008b), Moruya (Oliver et al., 2015), Guichen Bay (Murray Wallace et al., 2002; Bristow and Pucillo, 2006), Keppel Bay (Brooke et al., 2008a), Shark Bay (Nott, 2011), Cowley Beach (Nott et al., 2009), Lake Michigan (Thompson, 1992), St. Vincent Island (Lopez and Rink, 2008; Rink and Lopez, 2010), Jerup (Nielsen et al., 2006), Nayarit (Curray et al., 1969), and Rio Grande do Sul (Milana et al., 2017).

Our analyses show that during periods when the Usumacinta River was the main supplier of sandy sediments to the coast, changes in river discharge determined sediment availability, progradation rate, and the final elevation of the beach ridges. Since the river discharge is directly related to rainfall in the river catchment, beach-ridge elevation may be an excellent proxy for temporal changes in regional-scale precipitation.

Data availability. No data sets were used in this article. 
Appendix A: Additional tables

Table A1. AMS ${ }^{14} \mathrm{C}$-dated samples.

\begin{tabular}{|c|c|c|c|c|c|c|c|c|}
\hline & Sample & $\begin{array}{r}\text { Dist. along transect } \\
(\mathrm{m})\end{array}$ & GrA & Age BP & $1 \sigma$ & Extracted fraction & $\begin{array}{l}\mathrm{d}^{13} \mathrm{C} \\
(\% \circ)\end{array}$ & $\begin{array}{c}\mathrm{C} \\
(\%)\end{array}$ \\
\hline \multicolumn{9}{|c|}{ Transect A } \\
\hline & \multicolumn{8}{|c|}{ Debris layers within beach-ridge sands } \\
\hline & $429-250 \mathrm{~L}$ & 2110 & 58037 & 300 & 35 & Leaf fragments & -27.39 & 49.78 \\
\hline $\mathrm{A} 2^{1}$ & 393-300L & 3120 & 58032 & 715 & 35 & Leaf fragments & -30.25 & 45.26 \\
\hline $\mathrm{A} 2$ & 390-330L & 3375 & 59436 & 755 & 30 & Leaf fragments & -29.45 & 49.48 \\
\hline $\mathrm{A} 2$ & 389-330L & 3485 & 58031 & 900 & 40 & Leaf fragments & -30.48 & 52.21 \\
\hline $\mathrm{A} 2$ & $386-240 \mathrm{~L}$ & 3665 & 59755 & 820 & 40 & Leaf fragments & -31.97 & 51.93 \\
\hline $\mathrm{A} 2$ & $386-610 \mathrm{~L}$ & 3665 & 59751 & 940 & 50 & Leaf fragments & -30.52 & 49.28 \\
\hline $\mathrm{A} 2$ & $381-225 \mathrm{~L}$ & 4195 & 59753 & 935 & 35 & Leaf fragments & -31.12 & 55.98 \\
\hline $\mathrm{A} 2$ & $379-280 \mathrm{~L}$ & 4375 & 58030 & 1015 & 35 & Leaf fragments & -28.29 & 48.16 \\
\hline $\mathrm{A} 2$ & $378-280 \mathrm{~L}$ & 4475 & 59435 & 990 & 30 & Leaf fragments & -28.95 & 52.84 \\
\hline $\mathrm{A} 2$ & $376-290 \mathrm{~L}$ & 4710 & 59752 & 1075 & 40 & Leaf fragments & -28.29 & 42.98 \\
\hline $\mathrm{A} 2$ & 193-171L & 4890 & 55022 & 1250 & 30 & Leaf fragments & -30.05 & 61.50 \\
\hline $\mathrm{A} 2$ & $196-204 \mathrm{~L}$ & 4978 & 55023 & 1235 & 30 & Leaf fragments & -30.94 & 61.50 \\
\hline A2 & $396-270 \mathrm{~L}$ & 5330 & 59757 & 1255 & 40 & Leaf fragments & -30.94 & 51.96 \\
\hline $\mathrm{A} 2$ & 397-350L & 5415 & 58033 & 1390 & 35 & Leaf fragments & -30.06 & 54.93 \\
\hline A2 & $398-260 \mathrm{~S}$ & 5520 & 59437 & 1270 & 30 & Squash seed & -29.45 & 49.48 \\
\hline $\mathrm{A} 2$ & $413-270 \mathrm{~L}$ & 5595 & 59438 & 1415 & 30 & Leaf fragments & -28.72 & 50.93 \\
\hline A2 & $400-295 \mathrm{~L}$ & 5700 & 59694 & 1775 & 40 & Leaf fragments & -30.31 & 45.30 \\
\hline $\mathrm{A} 2$ & $481-290 \mathrm{~L}$ & 5755 & 60873 & 1490 & 35 & Leaf fragments & -29.65 & 51.11 \\
\hline $\mathrm{A} 2$ & $480-290 \mathrm{~L}$ & 5790 & 60871 & 1525 & 35 & Leaf fragments & -29.74 & 51.38 \\
\hline $\mathrm{A} 2$ & $426-885 \mathrm{~L}$ & 5935 & 58035 & 1665 & 35 & Leaf fragments & -29.92 & 45.92 \\
\hline \multirow[t]{10}{*}{$\mathrm{A} 2$} & $426-255 \mathrm{~L}$ & 5935 & 58034 & 1690 & 40 & Leaf fragments & -29.75 & 52.56 \\
\hline & $252-485 \mathrm{~L}$ & 8642 & 55021 & 2420 & 35 & Leaf fragments & -31.42 & 55.10 \\
\hline & $252-485 \mathrm{C}$ & 8642 & 55024 & 3290 & 30 & Charcoal & -24.66 & 73.70 \\
\hline & $336-368 \mathrm{~L}$ & 14222 & 54940 & 3410 & 45 & Leaf fragments & -29.7 & 38.70 \\
\hline & $336-368 \mathrm{C}$ & 14222 & 55025 & 3990 & 35 & Charcoal & -25.02 & 68.20 \\
\hline & \multicolumn{8}{|c|}{ Base of freshwater peat } \\
\hline & Pozpetr.-78- $82^{2}$ & & UtC-11 090 & 2055 & 59 & Charcoal/wood & -28.2 & \\
\hline & PP1-169-170 1 & & 53751 & 3220 & 40 & Charred plant fragments & -21.55 & 53.40 \\
\hline & \multicolumn{8}{|c|}{ Base of mangrove peat } \\
\hline & LC1-315-320 & & 55026 & 5030 & 35 & Charred plant fragments & -23.78 & 79.20 \\
\hline \multicolumn{9}{|c|}{ Transect B } \\
\hline \multicolumn{9}{|c|}{ Debris layers within beach-ridge sands } \\
\hline & $443-230 \mathrm{~L}$ & 1075 & 58041 & 165 & 35 & Leaf fragments & -28.11 & 50.18 \\
\hline & $444-150 \mathrm{~L}$ & 2270 & 58042 & 350 & 35 & Leaf fragments & -28.64 & 49.99 \\
\hline & $446-275 \mathrm{~L}$ & 4134 & 58043 & 1060 & 40 & Leaf fragments & -29.53 & 52.03 \\
\hline & $440-350 \mathrm{~L}$ & 6168 & 58040 & 2125 & 40 & Leaf fragments & -29.82 & 50.59 \\
\hline & $185-471 \mathrm{~L}$ & 7195 & 55029 & 2665 & 35 & Leaf fragments & -28.61 & 42.30 \\
\hline & $438-170 \mathrm{~L}$ & 7752 & 58039 & 3005 & 35 & Leaf fragments & -29.64 & 52.59 \\
\hline & $188-310 \mathrm{~L}$ & 10468 & 55020 & 3930 & 35 & Leaf fragments & -30.33 & 51.60 \\
\hline & $432-300 \mathrm{~L}$ & 10866 & 58144 & 3880 & 40 & Leaf fragments & -30.65 & 51.86 \\
\hline & \multicolumn{8}{|c|}{ Base of freshwater peat } \\
\hline & $307-405-410 \mathrm{~S}$ & 21901 & 64320 & 5420 & 70 & Asteraceae seeds & -28.08 & \\
\hline \multicolumn{9}{|c|}{ Transect C } \\
\hline & $469-160 \mathrm{~L}$ & & 58044 & 1210 & 35 & Leaf fragments & -29.63 & 49.70 \\
\hline & $469-325 \mathrm{~L}$ & & 58048 & 1360 & 35 & Leaf fragments & -29.51 & 46.92 \\
\hline
\end{tabular}

${ }^{1}$ Nooren et al. (2017); ${ }^{2}$ Nooren et al. (2009). 
Table A2. OSL-dated samples.

\begin{tabular}{|c|c|c|c|c|c|c|c|c|c|c|c|c|c|c|c|c|c|c|}
\hline \multirow{2}{*}{$\begin{array}{l}\text { Sample } \\
\text { Transect A }\end{array}$} & \multirow{2}{*}{ NCL code } & \multirow{2}{*}{$\begin{array}{l}\text { Lat. } \\
\left({ }^{o}\right)\end{array}$} & \multirow[t]{2}{*}{$\begin{array}{l}\text { Long. } \\
\left({ }^{o}\right)\end{array}$} & \multirow{2}{*}{$\begin{array}{l}\text { Comp. dist. }{ }^{1} \\
(\mathrm{~m})\end{array}$} & \multirow[t]{2}{*}{$\begin{array}{l}\text { Depth } \\
(\mathrm{m})\end{array}$} & \multirow[t]{2}{*}{$\begin{array}{l}\text { Elev. } \\
\text { (m a.m.s.l.) }\end{array}$} & \multicolumn{3}{|c|}{$\begin{array}{l}\text { Water content meas. used } \\
(\% \mathrm{dw})\end{array}$} & \multicolumn{2}{|c|}{$\begin{array}{l}\text { Organic content } \\
(\% \mathrm{dw})\end{array}$} & \multicolumn{2}{|c|}{$\begin{array}{l}\mathrm{U}^{238} \\
\left(\mathrm{Bqkg}^{-1}\right)\end{array}$} & \multicolumn{2}{|c|}{$\begin{array}{l}\mathrm{Th}^{232} \\
\left(\mathrm{Bqkg}^{-1}\right)\end{array}$} & \multicolumn{3}{|c|}{$\begin{array}{l}\mathrm{K}^{40} \\
\left(\mathrm{~Bq} \mathrm{~kg}^{-1}\right)\end{array}$} \\
\hline & & & & & & & & & \pm & & \pm & & \pm & & \pm & & \pm & \\
\hline 112 & NCL-4112227 & 18.595 & -92.594 & 3085 & 1.9 & 0 & 18.9 & 25 & 5 & 0.73 & 0.07 & 30.43 & 0.41 & 38.16 & 0.96 & 429 & 10 & \\
\hline 427 & NCL-1114072 & 18.570 & -92.596 & 5280 & 2.3 & 0 & 27.7 & 25 & 5 & 1.26 & 0.13 & 13.67 & 0.17 & 14.71 & 0.37 & 724 & 15 & \\
\hline 426 & NCL-4213072 & 18.568 & -92.595 & 5550 & 1.3 & 0 & 33.1 & 25 & 5 & 0.92 & 0.09 & 15.82 & 0.21 & 17.92 & 0.47 & 750 & 15 & \\
\hline 252 & NCL-4112229 & 18.549 & -92.575 & 7113 & 1.9 & 0 & 32.8 & 25 & 5 & 0.72 & 0.07 & 19.51 & 0.46 & 20.34 & 1.22 & 632 & 16 & \\
\hline \multicolumn{19}{|c|}{ Transect B } \\
\hline 443 & NCL-4213078 & 18.530 & -92.733 & 1075 & 1.6 & 0 & 25.9 & 25 & 5 & 0.87 & 0.09 & 20.50 & 0.32 & 23.05 & 0.76 & 577 & 13 & \\
\hline 444 & NCL-1114071 & 18.522 & -92.726 & 2270 & 0.8 & 0 & 27.0 & 25 & 5 & 0.85 & 0.09 & 19.84 & 0.31 & 19.73 & 0.67 & 635 & 14 & \\
\hline 445 & NCL-4213079 & 18.515 & -92.719 & 3255 & 1.05 & -0.05 & 29.0 & 25 & 5 & 0.84 & 0.08 & 14.83 & 0.27 & 15.26 & 0.68 & 725 & 15 & \\
\hline 179 & NCL-4112228 & 18.452 & -92.793 & 5750 & 0.55 & 1.55 & 4.7 & 5 & 3 & 1.78 & 0.18 & 18.87 & 0.30 & 23.12 & 1.58 & 612 & 13 & \\
\hline 440 & NCL-4213077 & 18.463 & -92.761 & 6168 & 1 & 0 & 23.2 & 25 & 5 & 0.77 & 0.08 & 17.61 & 0.22 & 19.95 & 0.49 & 624 & 13 & \\
\hline 438 & NCL-4213076 & 18.449 & -92.757 & 7752 & 0.92 & -0.32 & 26.2 & 25 & 5 & 0.52 & 0.05 & 16.13 & 0.28 & 19.16 & 0.67 & 627 & 13 & \\
\hline 436 & NCL-1114073 & 18.445 & -92.756 & 8199 & 2.2 & 0 & 24.8 & 25 & 5 & 0.87 & 0.09 & 15.72 & 0.23 & 18.32 & 0.53 & 643 & 13 & \\
\hline 437 & NCL-4213075 & 18.442 & -92.751 & 8678 & 1.5 & 0 & 29.9 & 25 & 5 & 1.00 & 0.10 & 18.22 & 0.30 & 21.42 & 0.74 & 661 & 14 & \\
\hline 435 & NCL-1114074 & 18.436 & -92.751 & 9272 & 1.3 & -0.1 & 25.2 & 25 & 5 & 0.93 & 0.09 & 18.03 & 0.28 & 20.24 & 0.66 & 679 & 14 & \\
\hline 434 & NCL-4213074 & 18.430 & -92.751 & 9953 & 2.7 & -0.1 & 25.8 & 25 & 5 & 1.05 & 0.11 & 14.56 & 0.25 & 16.65 & 0.68 & 658 & 14 & \\
\hline 433 & NCL-1114075 & 18.426 & -92.750 & 10398 & 1.5 & -0.1 & 26.1 & 25 & 5 & 0.68 & 0.07 & 18.86 & 0.23 & 21.46 & 0.50 & 632 & 13 & \\
\hline 432 & NCL-4213073 & 18.422 & -92.749 & 10866 & 1.1 & -0.1 & 25.1 & 25 & 5 & 0.25 & 0.03 & 14.78 & 0.26 & 16.49 & 0.66 & 594 & 13 & \\
\hline 450 & NCL-4213080 & 18.390 & -92.805 & 12637 & 1.05 & 0 & 20.9 & 25 & 5 & 0.58 & 0.06 & 13.06 & 0.24 & 15.49 & 0.61 & 529 & 12 & \\
\hline 451 & NCL-4213081 & 18.390 & -92.806 & 12684 & 1.48 & 1.17 & 3.1 & 5 & 3 & 0.86 & 0.09 & 12.18 & 0.17 & 13.66 & 0.35 & 566 & 12 & \\
\hline 452 & NCL-1114076 & 18.379 & -92.771 & 14412 & 1.6 & -0.1 & 24.5 & 25 & 5 & 0.63 & 0.06 & 14.69 & 0.17 & 16.62 & 0.33 & 595 & 12 & \\
\hline 459 & NCL-4213082 & 18.420 & -92.994 & & 0.7 & -0.1 & 22.0 & 25 & 5 & 0.58 & 0.06 & 14.64 & 0.27 & 18.95 & 0.70 & 540 & 12 & \\
\hline Sample & NCL code & \multicolumn{3}{|c|}{$\begin{array}{l}\text { Unatten. dose rate } \beta \gamma \\
\left(\mathrm{Gy} \mathrm{ka}^{-1}\right)\end{array}$} & & \multicolumn{2}{|c|}{$\begin{array}{l}\text { Cosmic radiation } \\
\left(\mathrm{Gy} \mathrm{ka}^{-1}\right)\end{array}$} & \multicolumn{2}{|c|}{$\begin{array}{l}\text { Burial dose }{ }^{2} \\
\text { (Gy) }\end{array}$} & \multicolumn{2}{|c|}{$\begin{array}{l}\text { Overdispersion } \\
(\%)\end{array}$} & $\begin{array}{l}\text { Dose } r \\
\text { (Gyka }\end{array}$ & & $\begin{array}{l}\text { Age } \\
\text { (ka) }\end{array}$ & & (yr CE) & & Validity \\
\hline Transect & & & \pm & & \pm & & \pm & & \pm & & \pm & & \pm & & \pm & & \pm & \\
\hline 112 & NCL-4112227 & 1.13 & 0.07 & 0.80 & 0.04 & 0.16 & 0.01 & 1.75 & 0.12 & 26 & 11 & 2.10 & 0.09 & 0.83 & 0.07 & 1182 & 70 & Likely OK \\
\hline 427 & NCL-1114072 & 1.39 & 0.09 & 0.65 & 0.03 & 0.15 & 0.01 & 3.6 & 0.2 & 30 & 4 & 2.20 & 0.1 & 1.65 & 0.12 & 363 & 120 & Questionable \\
\hline 426 & NCL-4213072 & 1.48 & 0.10 & 0.72 & 0.04 & 0.18 & 0.01 & 3.2 & 0.3 & 21 & 15 & 2.39 & 0.1 & 1.34 & 0.13 & 673 & 130 & Likely OK \\
\hline 252 & NCL-4112229 & 1.33 & 0.09 & 0.72 & 0.04 & 0.16 & 0.01 & 5.3 & 0.3 & 26 & 5 & 2.22 & 0.1 & 2.39 & 0.17 & -378 & 170 & Likely OK \\
\hline Transect I & & & & & & & & & & & & & & & & & & \\
\hline 443 & NCL-4213078 & 1.25 & 0.08 & 0.71 & 0.04 & 0.16 & 0.01 & 0.5 & 0.04 & 20 & 8 & 2.13 & 0.09 & 0.24 & 0.02 & 1773 & 20 & Likely OK \\
\hline 444 & NCL-1114071 & 1.33 & 0.09 & 0.71 & 0.04 & 0.19 & 0.01 & $0.86^{3}$ & 0.12 & 69 & 18 & 2.24 & 0.1 & 0.39 & 0.06 & 1623 & 60 & Likely OK \\
\hline 445 & NCL-4213079 & 1.41 & 0.09 & 0.67 & 0.04 & 0.18 & 0.01 & 1.79 & 0.08 & 7 & 6 & 2.28 & 0.1 & 0.79 & 0.05 & 1223 & 50 & OK \\
\hline 179 & NCL-4112228 & 1.60 & 0.09 & 0.86 & 0.05 & 0.20 & 0.01 & 2.9 & 0.3 & 33 & 9 & 2.66 & 0.1 & 1.08 & 0.12 & 932 & 120 & Questionable \\
\hline 440 & NCL-4213077 & 1.29 & 0.08 & 0.69 & 0.04 & 0.19 & 0.01 & 4.8 & 0.2 & 17 & 3 & 2.17 & 0.09 & 2.20 & 0.13 & -187 & 130 & OK \\
\hline 438 & NCL-4213076 & 1.30 & 0.08 & 0.69 & 0.04 & 0.19 & 0.01 & 5.9 & 0.2 & 10 & 4 & 2.18 & 0.09 & 2.71 & 0.15 & -697 & 150 & $\mathrm{OK}$ \\
\hline 436 & NCL-1114073 & 1.30 & 0.08 & 0.68 & 0.04 & 0.15 & 0.01 & 6.4 & 0.2 & 12 & 3 & 2.14 & 0.09 & 2.98 & 0.17 & -967 & 170 & OK \\
\hline 437 & NCL-4213075 & 1.36 & 0.09 & 0.72 & 0.04 & 0.17 & 0.01 & 7.8 & 0.4 & 18 & 6 & 2.26 & 0.1 & 3.47 & 0.23 & -1457 & 230 & $\mathrm{OK}$ \\
\hline 435 & NCL-1114074 & 1.36 & 0.09 & 0.69 & 0.04 & 0.18 & 0.01 & 7.8 & 0.4 & 16 & 5 & 2.25 & 0.1 & 3.46 & 0.23 & -1447 & 230 & OK \\
\hline 434 & NCL-4213074 & 1.31 & 0.09 & 0.66 & 0.04 & 0.14 & 0.01 & 7.8 & 0.4 & 23 & 4 & 2.13 & 0.09 & 3.67 & 0.25 & -1657 & 250 & Likely OK \\
\hline 433 & NCL-1114075 & 1.32 & 0.09 & 0.71 & 0.04 & 0.17 & 0.01 & 8.3 & 0.5 & 22 & 4 & 2.20 & 0.09 & 3.77 & 0.28 & -1757 & 280 & Likely OK \\
\hline 432 & NCL-4213073 & 1.21 & 0.08 & 0.63 & 0.03 & 0.18 & 0.01 & 8.7 & 0.5 & 23 & 4 & 2.03 & 0.09 & 4.27 & 0.33 & -2257 & 330 & Likely OK \\
\hline 450 & NCL-4213080 & 1.08 & 0.07 & 0.56 & 0.03 & 0.18 & 0.01 & 8.4 & 0.3 & 12 & 3 & 1.83 & 0.08 & 4.58 & 0.26 & -2567 & 260 & OK \\
\hline 451 & NCL-4213081 & 1.37 & 0.08 & 0.66 & 0.03 & 0.18 & 0.01 & 8.8 & 0.3 & 15 & 2 & 2.23 & 0.08 & 3.97 & 0.21 & -1957 & 210 & $\mathrm{OK}$ \\
\hline 452 & NCL-1114076 & 1.21 & 0.08 & 0.62 & 0.03 & 0.16 & 0.01 & 9.8 & 0.4 & 22 & 3 & 2.00 & 0.08 & 4.91 & 0.3 & -2897 & 300 & Likely OK \\
\hline 459 & NCL-4213082 & 1.13 & 0.07 & 0.61 & 0.03 & 0.19 & 0.01 & 2.73 & 0.13 & 11 & 3 & 1.94 & 0.08 & 1.41 & 0.09 & 603 & 90 & $\mathrm{OK}$ \\
\hline
\end{tabular}

Composite distance from current coastline (m) projected along Transect B (Fig. 3b).

The bootstrapped version of the central age model (Cunningham and Wallinga, 2012) was applied to determine the burial dose of the samples.

${ }^{3}$ For this sam
all samples. 
Table A3. Major-element composition (mean and SD) of volcanic glass and pumice fragments recovered from the beach-ridge sediments along Transect A. Oxide concentrations are normalised to $100 \%$ on a volatile-free basis. All iron is taken as FeO. The major-element composition of volcanic glass shards from Tierra Blanca III were generously provided by Hector V. Cabadas-Báez (Cabadas-Báez et al., 2017).

\begin{tabular}{|c|c|c|c|c|c|c|c|c|c|c|c|c|c|c|c|c|}
\hline Core & $\begin{array}{r}\text { Depth } \\
(\mathrm{m})\end{array}$ & $n$ & $\begin{array}{r}\mathrm{SiO}_{2} \\
(\%) \\
\pm\end{array}$ & $\begin{array}{c}\mathrm{TiO}_{2} \\
(\%) \\
\pm\end{array}$ & $\begin{array}{r}\mathrm{Al}_{2} \mathrm{O}_{3} \\
(\%) \\
\pm\end{array}$ & $\begin{array}{c}\mathrm{FeO} \\
(\%) \\
\pm\end{array}$ & $\begin{array}{c}\mathrm{MnO} \\
(\%) \\
\pm\end{array}$ & $\begin{array}{c}\mathrm{MgO} \\
(\%) \\
\pm\end{array}$ & $\begin{array}{c}\mathrm{CaO} \\
(\%) \\
\pm\end{array}$ & $\begin{array}{c}\mathrm{Na}_{2} \mathrm{O} \\
(\%) \\
\pm\end{array}$ & $\begin{array}{c}\mathrm{K}_{2} \mathrm{O} \\
(\%) \\
\pm\end{array}$ & $\begin{array}{c}\mathrm{P}_{2} \mathrm{O}_{5} \\
(\%) \\
\pm\end{array}$ & $\begin{array}{c}S \\
(\%) \\
\pm\end{array}$ & $\begin{array}{c}\mathrm{Cl} \\
(\%) \\
\pm\end{array}$ & $\begin{array}{c}\text { Total } \\
(\%)\end{array}$ & Before norm. \\
\hline 197 & 0.8 & 10 & 78.87 & 0.10 & 12.28 & 0.56 & 0.08 & 0.09 & 0.57 & 3.02 & 4.27 & 0.01 & 0.01 & 0.12 & 100 & 97.34 \\
\hline \multirow[t]{2}{*}{$193^{1}$} & 5 & 7 & 78.72 & 0.10 & 12.36 & 0.55 & 0.06 & 0.09 & 0.60 & 3.19 & 4.19 & 0.01 & 0.01 & 0.11 & 100 & 98.09 \\
\hline & & & 0.30 & 0.02 & 0.10 & 0.04 & 0.06 & 0.01 & 0.03 & 0.21 & 0.09 & 0.01 & 0.02 & 0.02 & & 0.49 \\
\hline 252 & 4.4 & 14 & 78.52 & 0.11 & 12.24 & 0.69 & 0.06 & 0.09 & 0.60 & 3.38 & 4.18 & 0.01 & 0.01 & 0.12 & 100 & 98.07 \\
\hline 252 & & & 0.19 & 0.02 & 0.17 & 0.07 & 0.05 & 0.01 & 0.04 & 0.20 & 0.15 & 0.01 & 0.03 & 0.01 & & 0.66 \\
\hline \multirow[t]{3}{*}{336} & 3.2 & 13 & 78.56 & 0.10 & 12.15 & 0.64 & 0.07 & 0.08 & 0.55 & 3.30 & 4.39 & 0.01 & 0.02 & 0.12 & 100 & 98.41 \\
\hline & & & 0.31 & 0.01 & 0.13 & 0.19 & 0.03 & 0.01 & 0.08 & 0.14 & 0.22 & 0.02 & 0.02 & 0.03 & & 0.39 \\
\hline & & & $\begin{array}{r}\mathrm{SiO}_{2} \\
(\%)\end{array}$ & $\begin{array}{c}\mathrm{TiO}_{2} \\
(\%)\end{array}$ & $\begin{array}{r}\mathrm{Al}_{2} \mathrm{O}_{3} \\
(\%)\end{array}$ & $\begin{array}{l}\mathrm{FeO} \\
(\%)\end{array}$ & $\begin{array}{c}\mathrm{MnO} \\
(\%)\end{array}$ & $\begin{array}{c}\mathrm{MgO} \\
(\%)\end{array}$ & $\begin{array}{l}\mathrm{CaO} \\
(\%)\end{array}$ & $\begin{array}{c}\mathrm{Na}_{2} \mathrm{O} \\
(\%)\end{array}$ & $\begin{array}{l}\mathrm{K}_{2} \mathrm{O} \\
(\%)\end{array}$ & $\begin{array}{c}\mathrm{BaO} \\
(\%)\end{array}$ & $\begin{array}{l}\mathrm{NiO} \\
(\%)\end{array}$ & $\begin{array}{c}\mathrm{Cr}_{2} \mathrm{O}_{3} \\
(\%)\end{array}$ & & \\
\hline
\end{tabular}

${ }_{1}^{1}$ Pumice clast of $1.5 \mathrm{~cm}$ diameter.

2 Tierra Blanca III (Cabadas-Báez et al., 2017).

\section{Appendix B: Additional figures}

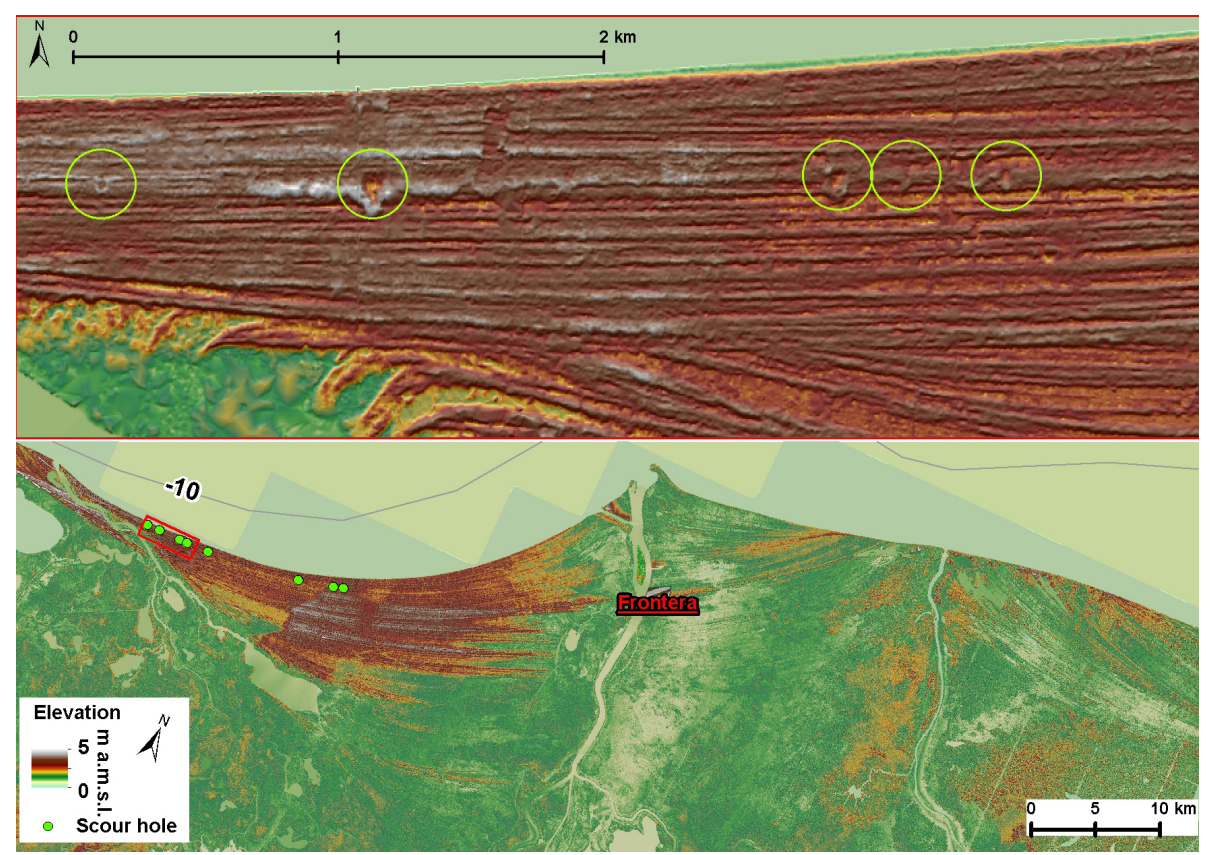

Figure B1. Scour holes along a beach ridge formed around $1450 \mathrm{CE}$. 


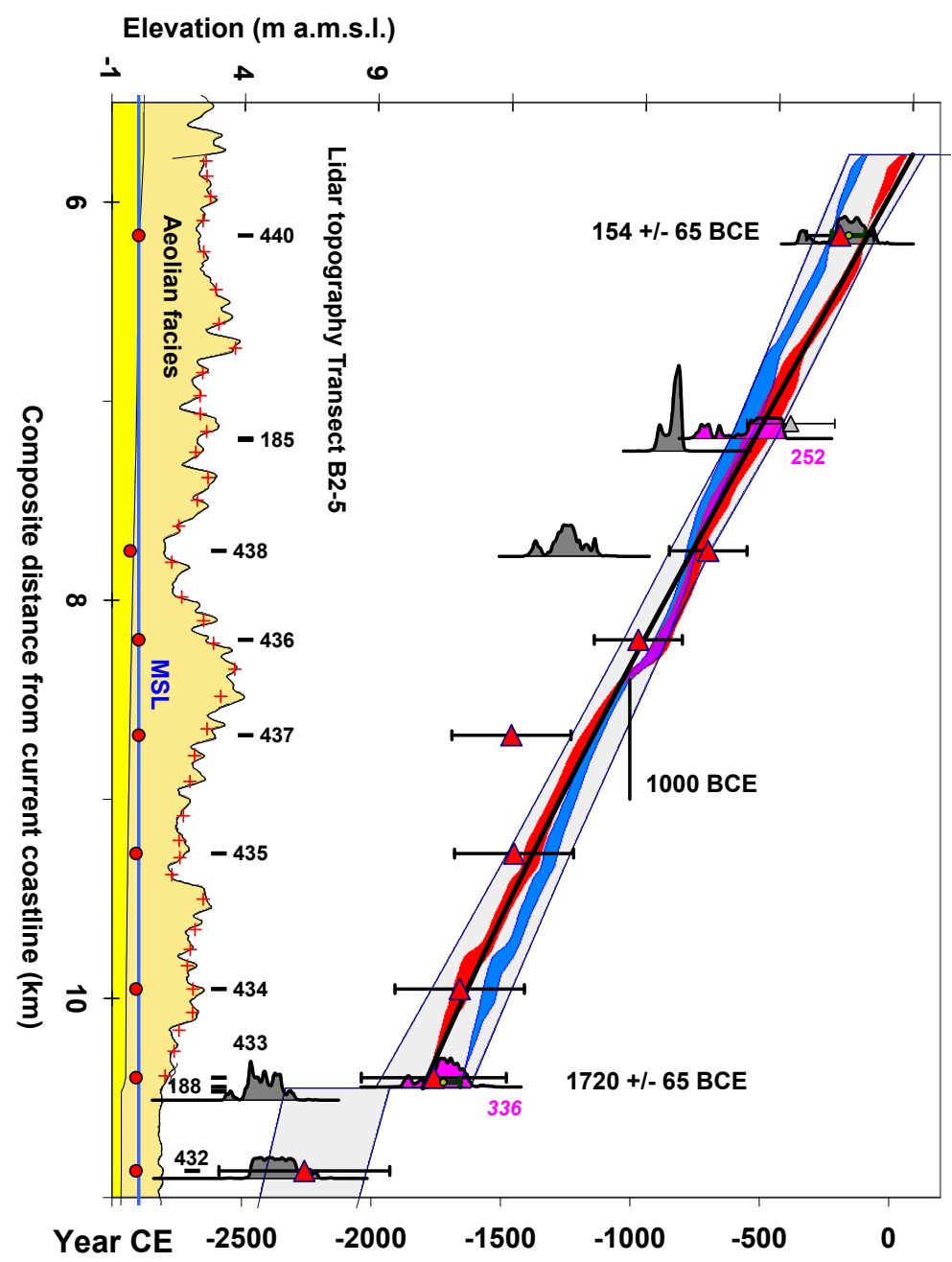

Figure B2. Age-distance scenarios for Transect B2, assuming a constant aeolian accretion rate in a shore-normal direction. The combined calibrated ages for OSL and AMS samples 440 and 433/336 (154 \pm 65 and 1720 \pm 65 BCE), calculated with Oxcal 4.2 (Bronk Ramsey, 2009) using the IntCal13 calibration curve (Reimer et al., 2013), are used as model boundaries. Indicated are five long-range (red) and five short-range (blue) scenarios for Transects B2-1 to B2-5. The calibrated $1 \sigma$ age range for a P_sequence model solely based on OSL ages (excluding sample 437) is indicated in grey. 

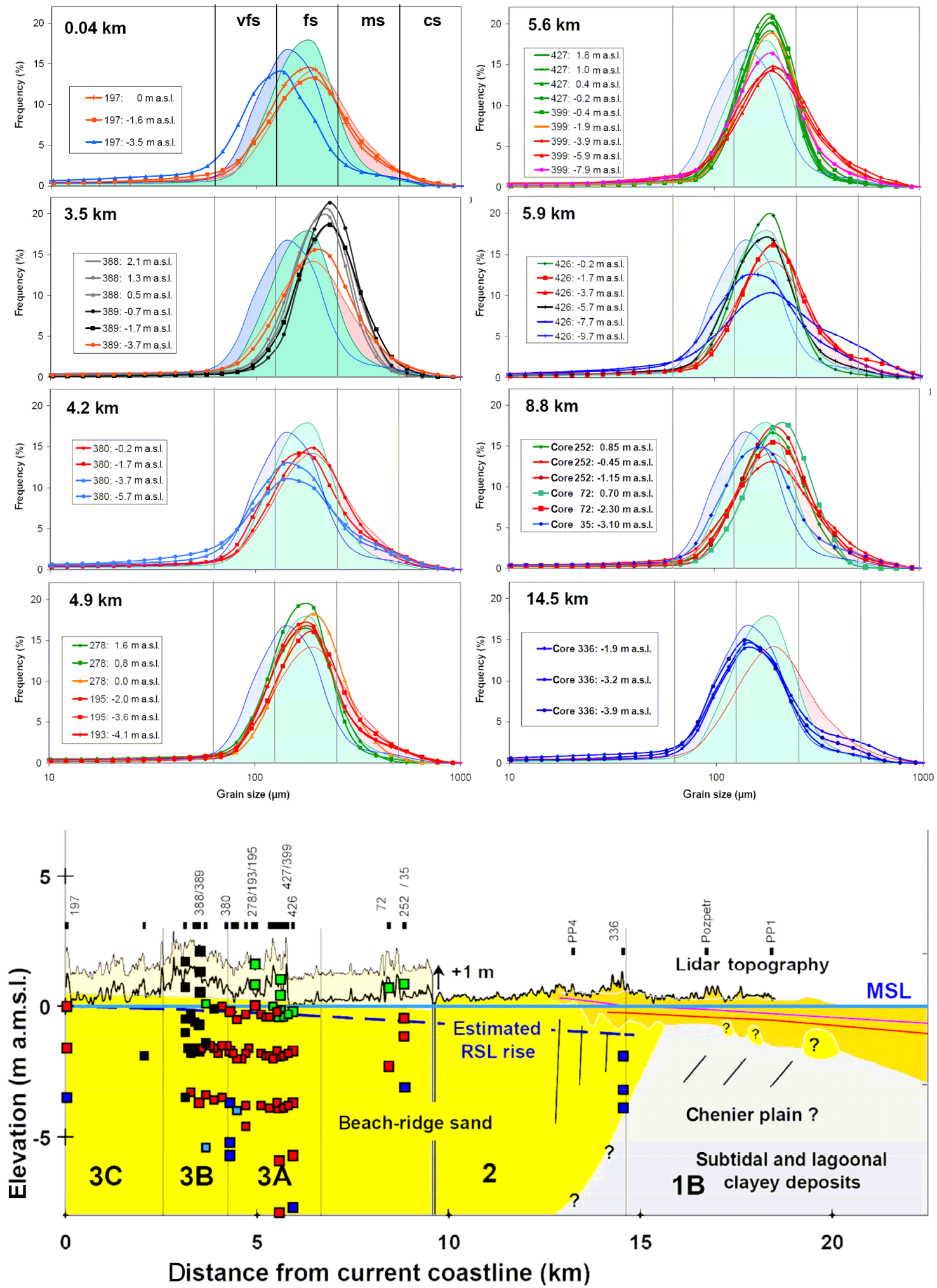

Figure B3. Variability in grain-size distribution of sand samples along Transect A at $0.04-14.5 \mathrm{~km}$ from the current coastline. Vfs: very fine sand; fs: fine sand; ms: medium sand; cs: coarse sand. Grain-size distributions of representative surficial samples from the current beach profile (Fig. 7b) are indicated for comparison. 

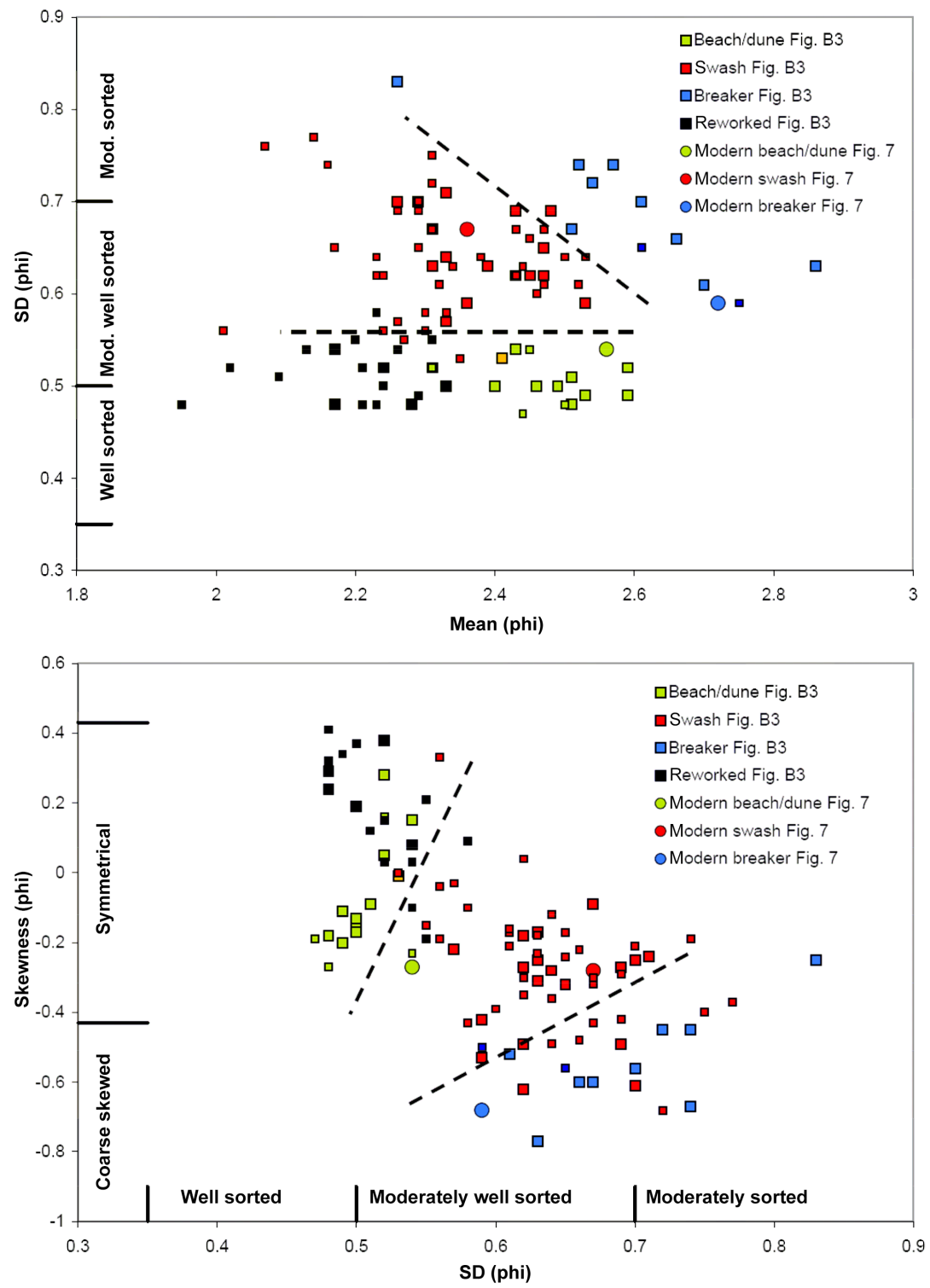

Figure B4. Grain-size statistical parameters calculated with the logarithmic method of moments (Blott and Pye, 2001). Sample locations are indicated in Fig. B3. 
Competing interests. The authors declare that they have no conflict of interest.

Acknowledgements. We thank INEGI, Mexico for the generous provision of the lidar data and Hector V. Cabadas-Báez for kindly supplying the major-element data of glass shards recovered from levee deposits at Tierra Blanca. Elise van Winden, Jesse Hennekam, and Ryan Nagelkirk provided field support and Salomon Kroonenberg offered valuable advice. We thank the reviewers, E. Otvos and T. Tamura, for their constructive comments that helped to improve the quality of the paper. This research is supported by the Netherlands Organisation for Scientific Research (NWO grant 821.01.007). Remke van Dam acknowledges support from the Michigan Space Grant Consortium.

Edited by: Francois Metivier

Reviewed by: Toru Tamura and Ervin Otvos

\section{References}

Aagaard, T., Davidson-Arnott, R., Greenwood, B., and Nielsen, J.: Sediment supply from shoreface to dunes: linking sediment transport measurements and long-term morphological evolution, Geomorphology, 60, 205-224, 2004.

Administración Portuaria Integral de Dos Bocas S. A. de C. V.: Manifestación de Impacto Ambiental Modalidad Particular; Construcción de Escolleras y del Dragado del Canal de Acceso del Puerto de Frontera, Tabasco. Administración Portuaria Integral de Dos Bocas S. A. de C. V., Paraíso, Tabasco, México, 258 pp., 2005.

Aguayo, J. E., Gutiérrez-Estrada, M. A., Araujo-Mendieta, J., Sandoval-Ochoa, J. H., and Vázquez-Gutiérrez, F.: Geodinámica Holocénica y reciente del sistema fluvio deltáico GrijalvaUsumacinta, suroeste del Golfo de México, Revista de la Sociedad Mexicana de Historia Natural, 49, 29-44, 1999.

Aitken, M. J.: An Introduction to Optical Dating: The Dating of Quaternary Sediments by the Use of Photon-Stimulated Luminescence, Oxford University Press, Oxford, 267 pp., 1998.

Ashton, A. D. and Giosan, L.: Wave-angle control of delta evolution, Geophys. Res. Lett., 38, L13405, https://doi.org/10.1029/2011GL047630, 2011.

Ayala-Castañares, A. and Guttiérrez-Estrada, M.: Morfología y sedimentos superficiales de la plataforma continental frente a Tabasco y Campeche, México, Anales del Instituto de Ciencias del Mar y Limnología, 17, 163-190, 1990.

Ballarini, M., Wallinga, J., Murray, A. S., Van Heteren, S., Oost, A. P., Bos, A. J. J., and Van Eijk, C. W. E.: Optical dating of young coastal dunes on a decadal time scale, Quaternary Sci. Rev., 22, 1011-1017, 2003.

Balsillie, J. H.: William F. Tanner on Environmental Clastic Granulometry, Special Publication 40, Geological Survey, Quaternary Science Reviews, Tallahassee, Florida, 145 pp., 1995.

Banco Nacional de Datos de Aguas Superficiales: available at: http://www.conagua.gob.mx/conagua07/contenido/documentos/ portadabandas.htm, last access: January 2017.
Blott, S. J. and Pye, K.: Gradistat: a grain size distribution and statistics package for the analysis of unconsolidated sediments, Earth Surf. Proc. Land., 26, 1237-1248, 2001.

Blum, M. D., Sivers, A. E., Zayac, T., and Goble, R. J.: Middle Holocene Sea-Level and Evolution of the Gulf of Mexico Coast, Gulf Coast Association of Geological Societies Transactions, Baton Rouge, Louisiana, 53, 64-77, 2003.

Bøtter-Jensen, L., Andersen, C. E., Duller, G. A. T., and Murray, A. S.: Developments in radiation, stimulation and observation facilities in luminescence measurement, Radiat. Meas., 37, 535-541, 2003.

Bristow, C. S. and Pucillo, K.: Quantifying rates of coastal progradation from sediment volume using GPR and OSL: the Holocene fill of Guichen Bay, south-east South Australia, Sedimentology, 53, 769-788, 2006.

Bronk Ramsey, C.: Bayesian analysis of radiocarbon dates, Radiocarbon, 51, 337-360, 2009.

Bronk Ramsey, C.: Oxcal 4.2., available at: http://c14.arch.ox.ac. uk/oxcal.html (last access: January 2017), 2016.

Brooke, B., Ryan, D., Pietsch, T., Olley, J., Douglas, G., Packett, R., Radke, L., and Flood, P.: Influence of climate fluctuations and changes in catchment land use on Late Holocene and modern beach-ridge sedimentation on a tropical macrotidal coast: Keppel Bay, Queensland, Australia, Mar. Geol., 251, 195-208, 2008a.

Brooke, B., Lee, R., Cox, M., Olley, J., and Pietsch, T.: Rates of shoreline progradation during the last 1700 years at Beachmere, Southeastern Queensland, Australia, based on optically stimulated luminescence dating of beach ridges, J. Coastal Res., 24, 640-648, 2008b.

Cabadas-Báez, H. V., Solís-Castillo, B., Solleiro-Rebolledo, E., Sedov, S., Leonard, D., and Teranishi-Castillo, K.: Reworked volcaniclastic deposits from the Usumacinta river, Mexico: a serendipitous source of volcanic glass in Maya ceramics, Geoarchaeology, 32, 382-399, 2017.

Carter, R. W. G.: The morphodynamics of beach-ridge formation: Magilligan, Northern Ireland, Mar. Geol., 73, 191-214, 1986.

Castillo, S., Pompa, J., and Moreno-Casasola, P.: Coastal sand dune vegetation of Tabasco and Campeche, Mexico, J. Veg. Sci., 2, 73-88, 1991.

Cleveringa, J.: Reconstruction and modelling of Holocene coastal evolution of the western Netherlands, PhD thesis, Utrecht University, Utrecht, the Netherlands, 2000.

Cunningham, A. C. and Wallinga, J.: Selection of integration timeintervals for quartz OSL decay curves, Quat. Geochronol., 5, 657-666, 2010.

Cunningham, A. C. and Wallinga, J.: Realizing the potential of fluvial archives using robust OSL chronologies, Quat. Geochronol., 12, 98-106, 2012.

Curray, J. R., Emmel, F. J., and Crampton, P. J. S.: Holocene history of a strand plain, lagoonal coast, Nayarit, Mexico, in: Lagunas Costeras, UN Symposium, edited by: Ayala-Casteñares, A. and Phleger, F. B., UNAM-UNESCO, Mexico, DF, 63-100, 1969.

Dogan, M., Van Dam, R. L., Bohling, G. C., Butler, J. J., and Hyndman, D. W.: Hydrostratigraphic analysis of the MADE site with full-resolution GPR and direct-push hydraulic profiling, Geophys. Res. Lett., 38, L06405, https://doi.org/10.1029/2010GL046439, 2011.

Donnelly, J. P. and Giosan, L.: Tempestuous highs and lows in the Gulf of Mexico, Geology, 36, 751-752, 2008. 
Drexler, J. W., Rose, W. I., Sparks, R. S. J., and Ledbetters, M. T.: The Los Chocoyos Ash, Guatemala: a major stratigraphic marker in middle America and in three ocean basins, Quaternary Res., 13, 327-345, 1980.

Duller, G. A. T.: Distinguishing quartz and feldspar in single grain luminescence measurements, Radiat. Meas., 37, 161-165, 2003.

FitzGerald, D. M., Buynevich, I. V., Fenster, M. S., and McKinlay, P. A.: Sand dynamics at the mouth of a rock-bound, tidedominated estuary, Sediment. Geol., 131, 25-49, 2000.

Folk, R. L. and Ward, W. C.: Brazos River bar: a study in the significance of grain size parameters, J. Sediment. Petrol., 27, 3-26, 1957.

Forrest, B. M.: Evolution of the Beach Ridge Strandplain on St. Vincent Island, Florida, Thesis, Florida State University, Tallahassee, 269 pp., 2007.

Forsyth, A. J., Nott, J., and Bateman, M. D.: Beach ridge plain evidence of a variable late-Holocene tropical cyclone climate, North Queensland, Australia, Palaeogeogr. Palaeocl., 297, 707$716,2010$.

Galbraith, R. F., Roberts, R. G., Laslett, G. M., Yoshida, H., and Olley, J. M.: Optical dating of single and multiple grains of quartz from Jinmium rock shelter, Northern Australia: part I, experimental design and statistical models, Archaeometry, 41, 339364, 1999.

Gallego-Fernández, J. B. and Martínez, M. L.: Environmental filtering and plant functional types on Mexican foredunes along the Gulf of Mexico, Ecoscience, 18, 52-62, 2011.

Garrison Jr., J. R., Mestas-Nuñez, A. M., Williams, J. R., and Lumb, L. M.: Can beach dune ridges of the Texas Gulf Coast preserve climate signals?, Geo-Mar. Lett., 32, 241-250, 2012.

Garrity, C. P. and Soller, D. R.: Database of the Geologic Map of North America, adapted from the map by J. C. Reed, Jr., and others (2005), US Geological Survey Data Series 424, available at: https://pubs.usgs.gov/ds/424/ (last access: January 2017), 2009.

Gischler, E. and Hudson, J. H.: Holocene development of the Belize barrier reef, Sediment. Geol., 164, 223-236, 2004.

Guedes, C. C. F., Giannini, P. C. F., Nascimento Jr., D. R. Sawakuchi, A. O., Tanaka, A. P. B., and Rossi, M. G.: Controls of heavy minerals and grain size in a holocene regressive barrier (Ilha Comprida, southeastern Brazil), J. S. Am. Earth Sci., 31, 110-123, 2011.

Guérin, G., Mercier, N., and Adamiec, G.: Dose-rate conversion factors: update, Ancient TL, 29, 5-8, 2011.

Harp, E. L., Wilson, R. C., and Wieczorek, G. F.: Landslides from the February 4, 1976, Guatemala earthquake, Prof. Paper 1024A, US Geological Survey, Washington, 1981.

Hijmans, R. J., Cameron, S. E., Parra, J. L., Jones, P. G., and Jarvis, A.:Very high resolution interpolated climate surfaces for global land areas, Int. J. Climatol., 25, 1965-1978, 2005.

Hinojosa, C., Nooren, K., Solleiro-Rebolledo, E., Sedov, S., Salazar, O.: Soil development on a beach ridge chronosequence in the Gulf of Mexico coastal plain and its relation to the ancient land use, Quatern. Int., 418, 180-194, 2016.

Hodell, D. A., Curtis, J. H., and Brenner, M.: Possible role of climate in the collapse of Classic Maya civilization, Nature, 375, 391-394, 1995.

Instituto Geográfico Nacional: Mapa Geológico de Guatemala a escala $1: 500,000$, Guatemala City, 1970.
Jol, H. M., Smith, D. G., and Meyers, R. A.: Digital ground penetrating radar (GPR): a new geophysical tool for coastal barrier research (examples from the Atlantic, Gulf and Pacific Coasts, USA), J. Coastal Res., 12, 960-968, 1996.

Jom Morán, S. A.: Medición batimétrica para determinar el volumen de material sedimentado acumulado durante el tiempo de servicio del embalse Pueblo Viejo, de la central hidroeléctrica Chixoy, Msc thesis, Universidad de San Carlos de Guatemala, Guatemala City, 2010.

Keijsers, J. G. S., Poortinga, A., Riksen, M. J. P. M., and Maroulis, J.: Spatio-temporal variability in accretion and erosion of coastal foredunes in the Netherlands: regional climate and local topography, PLoS ONE, 9, e91115, https://doi.org/10.1371/journal.pone.0091115, 2014.

Koch, A. J. and McLean, H.: Pleistocene tephra and ash-flow deposits in the volcanic highlands of Guatemala, Geol. Soc. Am. Bull., 86, 529-541, 1975.

Komar, P. D.: The entrainment, transport and sorting of heavy minerals by waves and currents, Dev. Sedimentol., 58, 3-48, 2007.

Kossin, J. P., Camargo, S. J., and Sitkowski, M.: Climate modulation of North Atlantic Hurricane tracks, J. Climate, 23, 3057-3076, 2010.

Kutterolf, S., Freundt, A., Peréz, W., Mörz, T., Schacht, U., Wehrmann, H., and Schmincke, H.-U.: Pacific offshore record of plinian arc volcanism in Central America: 1. Alongarc correlations, Geochem. Geophy. Geosy., 9, Q02S01, https://doi.org/10.1029/2007GC001631, 2008.

López, G. I. and Rink, W. J.: New quartz optical stimulated luminescence ages for beach ridges on the St. Vincent Island Holocene strand plain, Florida, US, J. Coastal Res., 24, 49-62, 2008.

May, J. H., Wells, S. G., Cohen, T. J., Marx, S. K., Nanson, G. C., and Baker, S. E.: A soil chronosequence on Lake Mega-Frome beach ridges and its implications for late Quaternary pedogenesis and paleoenvironmental conditions in the drylands of southern Australia, Quaternary Res., 83, 150-165, 2015.

McCave, I. N.: Grain-size trends and transport along beaches: example from eastern England, Mar. Geol., 28, M43-M51, 1978.

Milana, J. P., Conforti Ferreira Guedes, C., and Valdez Buso, V.: The coastal ridge sequence at Rio Grande do Sul: a new geoarchive for past climate events of the Atlantic coast of southern Brazil since the mid Holocene, Quatern. Int., 438, 187-199, 2017.

Milliken, K. T., Anderson, J. B., and Rodriguez, A. B.: A New Composite Holocene Sea-level Curve for the Northern Gulf of Mexico, Special Paper 443, The Geological Society of America, Boulder, 1-11, 2008.

Minderhoud, P., Cohen, K. M., Toonen, W. H. J., Erkens, G., and Hoek, W. Z.: Improving age-depth models of fluvio-lacustrine deposits using sedimentary proxies for accumulation rates, Quat. Geochronol., 33, 35-45, 2016.

Mook, W. G. and Van der Plicht, J.: Reporting ${ }^{14} \mathrm{C}$ activities and concentrations, Radiocarbon, 41, 227-239, 1999.

Moore, L. J., Durán Vinent, O., and Ruggiero, P.: Vegetation control allows autocyclic formation of multiple dunes on prograding coasts, Geology, 44, 559-562, 2016.

Morton, R. A., Paine, J. G., and Blum, M. D.: Responses of stable bay-margin and barrier-island systems to Holocene sea-level highstands, western Gulf of Mexico, J. Sediment. Res., 70, 478490, 2000. 
Muñoz-Salinas, E. Castillo, M., Sanderson, D., Kinnaird, T., and Cruz-Zaragoza, E.: Using three different approaches of OSL for the study of young fluvial sediments at the coastal plain of the Usumacinta-Grijalva River Basin, southern Mexico, Earth Surf. Proc. Land., 41, 823-834, 2016.

Murray-Wallace, C. V., Banerjee, D., Bourman, R. P., Olley, J. M., and Brooke, B. P.: Optically stimulated luminescence dating of Holocene relict foredunes, Guichen Bay, South Australia, Quaternary Sci. Rev., 21, 1077-1086, 2002.

Murray, A. S. and Wintle, A. G.: The single aliquot regenerative dose protocol: potential for improvements in reliability, Radiat. Meas., 37, 377-381, 2003.

Neal, A.: Ground-penetrating radar and its use in sedimentology: principles, problems and progress, Earth-Sci. Rev., 66, 261-330, 2004.

Nielsen, A., Murray, A. S., Pejrup, M., and Elberling, B.: Optically stimulated luminescence dating of a Holocene beach ridge plain in Northern Jutland, Denmark, Quat. Geochronol., 1, 305-312, 2006.

Nielsen, A. H., Elberling, B., and Pejrup, M.: Soil development rates from an optically stimulated luminescence-dated beach ridge sequence in Northern Jutland, Denmark, Can. J. Soil Sci., 90, 295-307, 2010.

Nieuwenhuyse, A. and Kroonenberg, S. B.: Volcanic origin of Holocene beach ridges along the Caribbean coast of Costa Rica, Mar. Geol., 120, 13-26, 1994.

Nooren, C. A. M., Hoek, W. Z., Tebbens, L. A., and Martin Del Pozzo, A. L.: Tephrochronological evidence for the late Holocene eruption history of El Chichón Volcano, Mexico, Geofísica Internacional, 48, 97-112, 2009.

Nooren, K., Hoek, W. Z., Van der Plicht, H., Sigl, M., Van Bergen, M. J., Galop, D., Torrescano-Valle, N., Islebe, G., Huizinga, A., Winkels, T., and Middelkoop, H.: Explosive eruption of El Chichón volcano (Mexico) disrupted 6th century Maya civilization and contributed to global cooling, Geology, 45, 175178, 2017.

Nott, J., Smithers, S., Walsh, K., and Rhodes, E.: Sand beach ridges record 6000 year history of extreme tropical cyclone activity in northeastern Australia, Quaternary Sci. Rev., 28, 1511-1520, 2009.

Nott, J.: A 6000 year tropical cyclone record from Western Australia, Quaternary Sci. Rev., 30, 713-722, 2011.

Oliver, T. S. N.: Holocene depositional history of three coastal sand ridge plains, southeastern Australia, Doctor of Philosophy thesis, School of Earth and Environmental Sciences, University of Wollongong, Wollongong, Australia, 216 pp., 2016.

Oliver, T. S. N., Dougherty, A. J., Gliganic, L. A., and Woodroffe, C. D.: Towards more robust chronologies of coastal progradation: optically stimulated luminescence ages for the coastal plain at Moruya, south-eastern Australia, Holocene, 25, 536-546, 2015.

Ollerhead, J., Davidson-Arnott, R., Walker, I. J., and Mathew, S.: Annual to decadal morphodynamics of the foredune system at Greenwich Dunes, Prince Edward Island, Canada, Earth Surf. Proc. Land., 38, 284-298, 2013.

Ortíz-Pérez, M. A.: Retroceso reciente de la línea ed costa del frente deltáico del Río San Pedro, Campeche-Tabasco, Investigaciones Geográficas, 25, 7-24, 1992.
Ortíz-Pérez, M. A., Hernández-Santana, J. R., Figueroa Mah Eng, J. M., and Gama Campillo, L.: Tasas del avance transgresivo y regresivo en el frente deltaico tabasqueño: en el período comprendido del año 1995 al 2008, in: Vulnerabilidad en las zonas costeras mexicanas ante el cambio climático, edited by: Botello, A. V., Villanueva-Fragoso, S., Gutiérrez, J., and Rojas Galaviz, J. L., UNAM-INE, Campeche, 305-324, 2010.

Otvos, E. G.: Beach Ridges - definitions and significance, Geomorphology, 32, 83-108, 2000.

Otvos, E. G.: Coastal barriers, Gulf of Mexico: holocene evolution and chronology, J. Coastal Res., 42, 141-163, 2005.

Padilla, R. J. and Sánchez: Evolución geológica del sureste mexicano desde el Mesozoico al presente en el contexto regional del Golfo de México, B. Soc. Geol. Mex., Tomo LIX, 1, 19-42, 2007.

Pietsch, T. J., Olley, J. M., and Nanson, G. C.: Fluvial transport as a natural luminescence sensitiser of quartz, Quat. Geochronol. 3, 365-376, 2008.

Prescott, J. R. and Hutton, J. T.: Cosmic ray distributions to dose rates for luminescence and ESR dating: large depths and longterm variations, Radiat. Meas., 23, 497-500, 1994.

Psuty, N. P.: Beach ridge development in Tabasco, Mexico, Ann. Am. Assoc. Geogr., 55, 112-124, 1965.

Psuty, N. P.: The Geomorphology of Beach Ridges in Tabasco, Mexico, Coastal Studies Series 18, Louisiana State University Press, Baton Rouge, USA, 51 pp., 1967.

Ramos, J., Marrufo, L., and González, F. J.: Use of lidar data in floodplain risk management planning: the experience of Tabasco 2007 flood, in: Advances in Geoscience and Remote Sensing, edited by: Jedlovec, G., Intech, Rijeka, Croatia, https://doi.org/10.5772/8322, 2009.

Reimann, T., Tsukamoto, S., Harff, J., Osadczuk, K., and Frechen, M.: Reconstruction of Holocene coastal foredune progradation using luminescence dating - An example from the Świna barrier (southern Baltic Sea, NW Poland), Geomorphology, 132, 1-16, 2011.

Reimer, P. J., Bard, E., Bayliss, A., Beck, J. W., Blackwell, P. G., Ramsey, C. B., Buck, C. E., Cheng, H., Edwards, R. L., Friedrich, M., Grootes, P. M., Guilderson, T. P., Haflidason, H., Hajdas, I., Hatte, C., Heaton, T. J., Hoffmann, D. L., Hogg, A. G., Hughen, K. A., Kaiser, K. F., Kromer, B., Manning, S. W., Niu, M., Reimer, R. W., Richards, D. A., Scott, E. M., Southon, J. R., Staff, R. A., Turney, C. S. M., and Van der Plicht, J.: IntCal13 and Marine13 radiocarbon age calibration curves 050,000 years cal BP, Radiocarbon, 55, 1869-1887, 2013.

Rémillard, A. M., Buylaert, J.-P., Murray, A. S., St-Onge, G., Bernatches, P., and Hetu, B.: Quartz OSL dating of the late Holocene beach ridge from the Magdalen Islands (Quebec, Canada), Quat. Geochronol., 30, 264-269, 2015.

Rink, W. J. and López, G. I.: OSL-based lateral progradation and aeolian sediment accumulation rates for the Apalachicola Barrier Island Complex, North Gulf of Mexico, Florida, Geomorphology, 123, 330-342, 2010.

Rose, W. I., Newhall, C. G., Bornhorst, T. J., and Self, C.: Quaternary silicic pyroclastic deposits of Atitlán Caldera, Guatemala, J. Volcanol. Geoth. Res., 33, 57-80, 1987.

Salas-de-León, D. A., Monreal-Gómez, M. A., Salas-Monreal, D., Riverón-Enzástiga, M. L., and Sánchez-Santillan, N. L.: Inter-annual sea level variability in the southern Gulf of 
Mexico (1966-1976), Geophys. Res. Lett., 33, L08610, https://doi.org/10.1029/2006GL025832, 2006.

Salas-de-León, D. A., Monreal-Gómez, M. A., Miguel DíazFlores, M. A., Salas-Monreal, D., Velasco-Mendoza, H., Riverón-Enzástiga, M. L., and Ortiz-Zamora, G.: Role of nearbottom currents in the distribution of sediments within the Southern Bay of Campeche, Gulf of Mexico, J. Coastal Res., 24, 14871494, 2008.

Sánchez-Núñez, M. M., Macías, J. L., Saucedo, R., Zamorano, J. J., Novelo, D., Mendoza, M. E., and Torres-Hernández, J. R.: Geomorphology, internal structure and evolution of alluvial fans at Motozintla, Chiapas, Mexico, Geomorphology, 230, 1-12, 2015.

Scheffers, A., Engel, M., Scheffers, S., Squire, P., and Kelletat, D.: Beach ridge systems - archives for Holocene coastal events?, Prog. Phys. Geogr., 36, 5-37, 2012.

Shepherd, M. J.: Relict and contemporary foredunes as indicators of coastal processes, in: Applied Quaternary Studies, edited by: Brierley, G. and Chappell, J., Australian National University, Canberra, Australia, 17-24, 1991.

Solís-Castillo, B., Thiel, C., Cabadas-Báez, H., SolleiroRebolledo, E., Sedov, S., Terhorst, B., Damm, B., Frechen, M., and Tsukamoto, S.: Holocene sequences in the Mayan Lowlands - A provenance study using heavy mineral distributions, Eiszeitalter und Gegenwart, Quaternary Sci. J., 62, 84-97, 2013.

Stapor, F. W., Jr., Mathews, T. D., and Lindfors-Kearns, F. E.: Barrier-island progradation and holocene sealevel history in southwest Florida, J. Coastal Res., 7, 815-838, 1991.

Tamura, T.: Beach ridges and prograded beach deposits as palaeoenvironment records, Earth-Sci. Rev., 114, 279-297, 2012.

Tamura, T., Murakami, F., and Watanabe, K.: Holocene beach deposits for assessing coastal uplift of the northeastern Boso Peninsula, Pacific coast of Japan, Quaternary Res., 74, 227-234, 2010.

Tanner, W. F.: Late Holocene sea-level changes from grain-size data: evidence from the Gulf of Mexico, Holocene, 2, 249-254, 1992.

Tanner, W. F.: Origin of beach ridges and swales, Mar. Geol., 129, 149-161, 1995.

Taylor, M. J. and Stone, G. W.: Beach-ridges: a review, J. Coastal Res., 12, 612-621, 1996.

Thompson, T. A.: Beach-ridge development and lake-level variation in southern Lake Michigan, Sediment. Geol., 80, 305-318, 1992.

Törnqvist, T. E., Gonzalez, J. L., Newsom, L. A., van der Borg, K., de Jong, A. F. M., and Kurnik, C. W.: Deciphering holocene sealevel history on the U.S. Gulf Coast: a high-resolution record from the Mississippi Delta, Geol. Soc. Am. Bull., 116, 10261039, 2004.
Tsukamoto, S., Rink, W. J., and Watanuki, T.: OSL of tephric loess and volcanic quartz in Japan and an alternative procedure for estimating De from a fast OSL component, Rad. Meas., 37, 459465, 2003.

USGS: Shuttle Radar Topography Mission (SRTM) 1 Arc-Second Global dataset, available at: https://lta.cr.usgs.gov/SRTM1Arc (last access: January 2017), 2009.

Van Dam, R. L.: Landform characterization using geophysics - recent advances, applications, and emerging tools, Geomorphology, 137, 57-73, 2012.

Van Dam, R. L. and Schlager, W.: Identifying causes of groundpenetrating radar reflections using time-domain reflectometry and sedimentological analyses, Sedimentology, 47, 435-449, 2000.

Van der Meene, E. A., Van der Staay, J., and Lay Hock, T.: The Van der Staay suction - corer - a simple apparatus for drilling in sand below groundwater table, Rijks Geologische Dienst, Haarlem, the Netherlands, 1979.

Van der Plicht, J., Wijma, S., Aerts, A. T., Pertuisot, M. H., and Meijer, H. A. J.: The Groningen AMS facility: status report, Nucl Instrum. Meth. B, 172, 58-65, 2000.

Van Heteren, S., Fitzgerald, D. M., Mckinlay, P. A., and Buynevich, I. V.: Radar facies of paraglacial barrier systems: coastal New England, USA, Sedimentology, 45, 181-200, 1998.

Van Overmeeren, R. A.: Radar facies of unconsolidated sediments in the Netherlands: a radar stratigraphy interpretation method for hydrogeology, J. Appl. Geophys., 40, 1-18, 1998.

Vespremeanu-Stroe, A., Preoteasa, L., Zăinescu, F., Rotaru, S., Croitoru, L., and Timar-Gabor, A.: Formation of Danube delta beach ridge plains and signatures in morphology, Quatern. Int., 415, 268-285, 2016.

Von Nagy, C.: Of Meandering Rivers and Shifting Towns: Landscape Evolution and Community within the Grijalva delta. $\mathrm{PhD}$ thesis, Tulane University, USA, 1640 pp., 2003.

Visher, G. S.: Grain size distributions and depositional processes, J. Sediment. Petrol., 39, 1074-1106, 1969.

Wahl, D., Byrne, R., and Anderson, L.: An 8700 year paleoclimate reconstruction from the southern Maya lowlands, Quaternary Sci. Rev., 103, 19-25, 2014.

Wallinga, J.: Optically stimulated luminescence dating of fluvial deposits: a review, Boreas, 31, 303-322, 2002.

West, R. C., Psuty, N. P., and Thom, B. G.: The Tabasco Lowlands of Southeastern Mexico, Technical Report 70, Louisiana State University, Baton Rouge, USA, 198 pp., 1969. 